Universidade de São Paulo

\title{
A física da música no Renascimento: uma abordagem histórico-epistemológica
}

\author{
Rafael Andrade Pereira
}




\title{
Universidade de São Paulo \\ Instituto de Física \\ Instituto de Química \\ Instituto de Biociências \\ Faculdade de Educação
}

\section{A física da música no Renascimento: uma abordagem histórico-epistemológica}

\author{
Rafael Andrade Pereira
}

Orientador: Prof. Dr. Oscar João Abdounur

\begin{abstract}
Dissertação de mestrado apresentada ao Instituto de Física, ao Instituto de Química, ao Instituto de Biociências e a Faculdade de Educação da Universidade de São Paulo, para a obtenção do título de Mestre em Ensino de Ciências.
\end{abstract}

São Paulo

2010 
FICHA CATALOGRÁFICA

Preparada pelo Serviço de Biblioteca e Informação do Instituto de Física da Universidade de São Paulo

Pereira, Rafael Andrade

A física da música no renascimento: uma abordagem histórico-epistemológica. São Paulo, 2010.

Dissertaçăo (Mestrado) - Universidade de São Paulo. Faculdade de Educação, Instituto de Flsica, Instituto de Química e Instituto de Biociências

Orientador: Prof. Dr. Oscar João Abdounur

Area de Concentraçăo: Ensino de Fisica

Unitermos: 1. Acústica Musical; 2. Renascimento; 3. Ensino de física; 4. Epistemologia; 5. Exposiçăo Didática.

USP/IF/SBI-069/2010 


\section{DEDICATÓRIA}

Dedico este trabalho aos meus pais José Pereira e Telma Andrade Pereira, aos meus irmãos Augusto e Patrícia, à minha esposa Mariana de Oliveira Faria e ao meu primo Rodrigo Andrade Zampieri que infelizmente não está mais entre nós. 


\section{AGRADECIMENTOS}

Agradeço a meu orientador Oscar João Abdounur por me orientar e colaborar com meu desenvolvimento acadêmico, profissional e pessoal.

À meus pais José Pereira e Telma Andrade Pereira, meus irmãos Augusto Andrade Pereira

e Patrícia Cristina Andrade Pereira, e minha esposa Mariana de Oliveira Faria pelo apoio, amor, dedicação e cooperação que sempre me deram.

Ao meu amigo e companheiro de trabalho Alex de Lima Barros e sua esposa Flávia L. por todo apoio que me deram ao longo do mestrado, sobretudo na finalização da dissertação.

À minha família, em particular tia Ceça, tio Tadeu, Digo, Tato e Renata e meus amigos Vlademir, Renato, Marcelão, Marcelo Naudi, Luizinho, Marcelinho, André, Henrique, Gustavo, Talita, Ricardo (Cabelo), Felipe, Kátia, Paulinho, Sônia, Sil, João e Aninha que sempre me apoiaram.

Ao meu grupo de pesquisa Luís, Eliezer, Yumi, Luana, Delma e Diana, e a todos que contribuíram e estiveram de algum modo presentes durante este percurso, muito obrigado! 


\section{RESUMO}

Este trabalho objetiva pesquisar sob uma perspectiva histórico-epistemológica o desenvolvimento da acústica musical no Renascimento. Tal investigação será especialmente focada na busca de indicadores da importância da verificação experimental na produção do conhecimento acústico nesse período. Com o intuito de extrair os indicadores mencionados, assim analisou-se tratados teórico-musicais desse período sob uma perspectiva das relações entre a física, a matemática e a música. Do ponto de vista educacional, o presente projeto pretende, por meio de uma exposição didática no museu Estação Ciência, reproduzir estruturalmente experimentos esclarecedores de conceitos acústicos emergentes na Revolução Científica, fazendo uso de recursos modernos. Como resultado bibliográfico de tais reflexões, foi organizada uma discussão sobre um conjunto de estratégias de ensino sobre a relação entre física, matemática e música, sob uma perspectiva histórico-epistemológica.

Além disso, o presente trabalho relatou o processo de desenvolvimento de uma exposição didática sobre a relação entre a matemática, a física e a música. Tal exposição busca reconstruir os principais experimentos da história da acústica musical responsáveis pela consolidação da teoria que conhecemos atualmente, evidenciando os indicadores da importância da verificação experimental na produção do conhecimento acústico na história da ciência. Neste sentido, torna-se fundamental que a pesquisa historiográfica forneça subsídios teóricos para a fundamentação da transição de uma ciência musical centrada em um dogmatismo aritmético para uma ciência musical, que tem a verificação experimental como critério relevante de falseamento de suas teorias. Desta forma, o presente trabalho pretende apresentar a exposição didática que será realizada no museu Estação Ciência, reproduzindo por escrito sua estrutura, experimentos e painéis que visam esclarecer conceitos acústicos emergentes na Grécia Antiga e suas transformações ao longo da Revolução Científica.

Palavras-Chave: Exposição / Divulgação Científica / Acústica Musical / Epistemologia Histórica / Experimentação 


\begin{abstract}
This project aims to research under a historic-epistemological perspective the development of musical acoustic in the Renaissance. This research will be especially focused in the search for indicators of the importance of experimental verification in the production of acoustic knowledge of that time. Therefore, it becomes essential that the historiografical search provide theoretical subsidies for reasoning of the transition from a science musical centered on a dogmatism arithmetic to a science musical, which has a verification test as a relevant criterion of distorted from their theories. In order to extract the indicators mentioned, the aim is to analyze well-treated theoretical music of this period under the prospect of relations between the physics, mathematics and music. From an educational overview, this project intends, through a didactic exhibition at the museum "Estação Ciência", to reproduce structurally clarifying experiments of acustical concepts emerged in the Scientific Revolution, making use of modern resources. As a result of such bibliographic thoughts, it is intended to discuss various teaching strategies on the development of the relationship between physics, mathematics and music, on a perspective historic-epistemological.

Then this project aims to describe the process of the development of a didactic exposition about the relation between mathematics, physics and music under a historicepistemological perspective. Such exposition intends to reconstruct the main experiments of the acoustics musical history, which are responsible for the consolidation of the theory that is currently known, evidencing the points of the importance on the experimental verification in the production of the acoustic knowledge, in the history of science. In this direction, it is extremely important that this research provides theoretical subsidies to the implementation of a transition between a centered musical science and an arithmetical dogmatism for a musical science which has the experimental verification as a relevant criteria of falsifiability of its theories. In doing so, this project intends to present the didatic exposition that will be carried out in the museum "Estação Ciência", reproducing, in writing, its structure, experiments and panels that aim to clarify emergent acoustic concepts in Old Greece and its transformations throughout the Scientific Revolution.
\end{abstract}

Keywords: Exposition / Scientific Divulgation / Musical Acoustic / Historical Epistemology / Empiricism. 


\section{SUMÁRIO}

PREFÁCIO

CAPÍTULO 1 ........................................................................14 14

INTRODUÇÃ O....................................................................14

1.1 Delimitando o problema de pesquisa............................................................................... 14

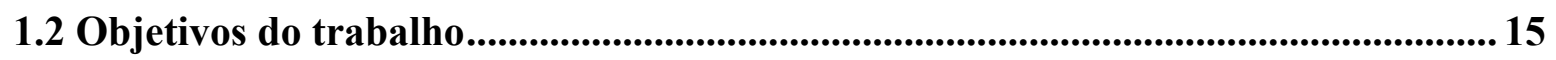

1.3 Pressupostos básicos e a metodologia de pesquisa ............................................. 15

$1.4 \mathrm{O}$ ensino da relação entre a física e a música ................................................... 16

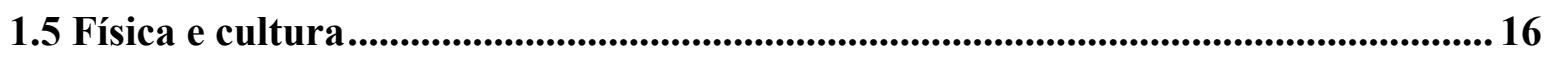

1.6 Conceitos introdutórios de música...................................................................................... 17

1.6.1 Intervalos Musicais................................................................................ 17

1.6.2 Notas e Acordes: Um estudo de harmonia ..................................................... 19

1.6.3 Consonâncias e dissonâncias .......................................................................21

CAPÍTULO 2

\section{A FÍSICA DA MÚSICA: DOS GREGOS À MÚSICA} CONTEMPORÂNEA..........................................................23

$2.1 \mathrm{O}$ Monocórdio e suas consequências................................................................. 23

2.2 A crítica ao pensamento pitagórico e o nascimento de uma nova ciência............... 27

$2.3 \mathrm{O}$ temperamento igual e outros temperamentos .................................................29

2.4 As cordas vibrantes, seus modos de vibração, o princípio de Superposição e a

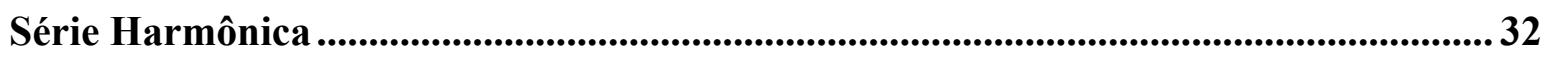

2.5 O timbre visto a partir da relação entre a Série Harmônica e a Série de Fourier 34

2.6 Análises sobre o conceito de consonância............................................................35

2.70 tratado de Jean Philipe Rameau ................................................................. 37

2.8 A música ocidental e o surgimento de um novo paradigma ..................................... 39 


\section{A ACÚSTICA MUSICAL SOB UMA ÓTICA}

HISTÓRICO-EPISTEMOLÓGICA...................................41

3.1 A epistemologia de Thomas Kuhn .................................................................................. 41

3.2 As escolhas epistemológicas para a releitura da Acústica Musical.........................44

3.3 O nascimento da Acústica como uma ciência experimental...................................... 45

3.4 A natureza da ciência e o ensino de Acústica............................................................47

3.5 A epistemologia de Kuhn, o ensino de Acústica e a natureza da ciência.................. 48

3.6 O Renascimento: Uma Revolução Científica generalizada? .....................................49

3.7 Uma discussão sobre o currículo de física do Ensino Médio ...............................50

\section{CAPÍTULO 4 ......................................................................52}

A ELABORAÇÃO DA EXPOSIÇÃO DIDÁTICA .........52

4.1 Sala 1: Motivações e questões relevantes para a compreensão da Série Harmônica

4.2 Sala 2: O experimento do Monocórdio: razões $\mathrm{x}$ intervalos musicais $\mathrm{e}$ a sistematização matemática da escala ...............................................................56

4.3 Sala 3: Renascimento: o nascimento da música como ciência experimental ...........59

4.4 Sala 4: Escalas e Temperamento..................................................................6 61

4.5 Sala 5: Série Harmônica/Série de Fourier ................................................................. 63

4.6 Sala 6: Consonância e Dissonância: do simbolismo aritmético a uma concepção

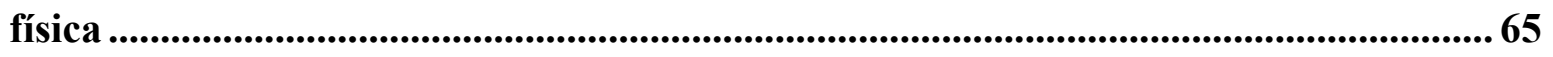

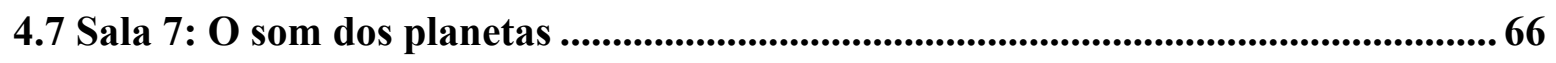

4.8 Sala 8: Da matemática-especulativa à matemática-empírica: uma revolução científica na música .............................................................................................................. 67

4.9 Considerações gerais sobre a realização da exposição ....................................... 68 
CAPÍTULO 5 ..................................................................

IMPLICAÇÕES EDUCACIONAIS: .................................71

DIVERSIFICANDO AS ESTRATÉGIAS DE ENSINO71

5.1 A física dos instrumentos musicais .............................................................. 71

5.2 Da sensibilização musical à sistematização dos conceitos físicos da ondulatória ... 72

5.3 Diversificando as estratégias de ensino ................................................................. 73

5.3.1 O uso de softwares e a relação entre as qualidades do som e os elementos de uma

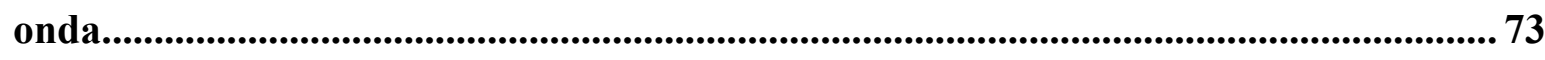

5.3.2 A construção de instrumentos musicais como uma estratégia de ensino de

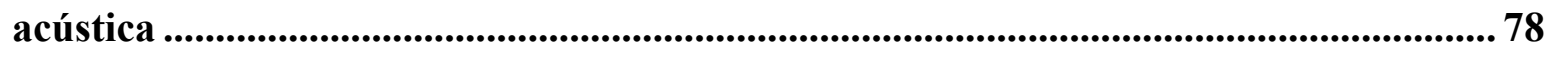

5.3.3 A entrevista com músicos e a reflexão sobre a física da música............................ 79

5.3.4 A leitura de textos históricos e a construção de diálogos fictícios ......................... 79

$5.3 .5 \mathrm{O}$ uso de vídeos, imagens e sons .............................................................................. 93

5.3.6 A experimentação e a construção de conceitos ................................................. 94

5.4 A profundidade e a generalidade desta discussão ............................................97

6. CONSIDERAÇÕES FINAIS ...........................................98

7. GLOSSÁRIO FÍSICO-MUSICAL...............................100

8. REFERÊNCIAS BIBLIOGRÁFICAS..........................104 


\section{PREFÁCIO}

Este trabalho consiste essencialmente em um estudo sobre a física da música no Renascimento sob uma perspectiva histórico-epistemológica, e suas implicações no âmbito do ensino de física e da divulgação científica.

Para isso, realizou-se uma pesquisa historiográfica que possibilitou a elaboração de um recorte do desenvolvimento histórico da Acústica. Tal recorte foi analisado à luz da epistemologia de Thomas Kuhn. Como produto deste trabalho, organizou-se uma proposta de exposição que será realizada na Estação Ciência ${ }^{1}$. Tal exposição tem previsão de acontecer em fevereiro de 2011 e está sendo financiada pelo CNPq e pela FAPESP.

Pretende-se com esta dissertação evidenciar as potencialidades e implicações educacionais do ensino de Acústica. Além disso, buscou-se apresentar uma discussão visando ampliar o repertório e estratégias de trabalho dos professores de física acerca deste tema.

Sob uma perspectiva estrutural, esta dissertação está dividida em 5 capítulos:

Capítulo 1: Introdução - Neste capítulo será apresentado o problema e os objetivos da pesquisa, e uma breve introdução aos conceitos musicais que serão explorados ao longo do trabalho.-

Capítulo 2: A física da música: Dos gregos à música contemporânea - Trata-se de uma apresentação de um recorte da história da relação físico-musical dos gregos até os dias atuais com especial enfoque no Período do Renascimento.-

Capítulo 3: A Acústica Musical sob uma perspectiva histórico-epistemológica - Neste capítulo será discutido o projeto epistemológico de Thomas Kuhn e a partir do recorte 
histórico apresentado no capítulo anterior será realizada uma análise sobre a Revolução Científica que ocorreu no Renascimento na Acústica Musical.-

Capítulo 4: A elaboração da Exposição Didática - Este capítulo apresentará um projeto da Exposição Didática. Apresentaremos os elementos que fundamentam as concepções e estrutura desta Exposição.-

Capítulo 5: Implicações Educacionais: a física, os instrumentos musicais e as estratégias de ensino de Acústica - Pretende-se neste Capítulo apresentar principalmente aos professores de física possibilidades de exploração dos elementos trazidos nos capítulos anteriores, buscando levar a discussão apresentada para a sala de aula. Assim, este capítulo tem a pretensão de evidenciar um conjunto de estratégias de ensino que se mostraram eficientes ao longo de realizações de oficinas e projetos de ensino de Acústica realizados ao longo do mestrado.-

\footnotetext{
${ }^{1}$ A Estação Ciência é um museu de divulgação científica localizado na cidade de São Paulo.
} 


\section{CAPÍTULO 1 \\ INTRODUÇÃO}

\subsection{Delimitando o problema de pesquisa}

Esta dissertação pretende abordar diversas perspectivas da relação entre a Acústica musical e seu ensino. Neste sentido, este material apresentará uma maneira de se entender como o ensino da relação entre a física e a música pode colaborar com a formação dos estudantes de ensino médio. Assim, optou-se pelas seguintes questões norteadoras:

- Como o ensino da acústica musical pode colaborar com o tratamento da natureza da ciência no ensino médio?

- Como a experimentação e a história da ciência podem colaborar com o processo de ensino-aprendizagem da acústica? Quais estratégias podem potencializar este processo?

- Em que medida uma exposição didática de acústica fortalece o enfoque históricoepistemológico do ensino deste tema?

Uma análise em livros didáticos e currículos de física evidenciam que a acústica musical é um assunto ou praticamente ausente na maior parte dos cursos ou, quando contemplado, é feito de maneira superficial. Dentre os obstáculos à inserção deste tema no currículo do ensino médio, estão a fragilidade da formação musical dos estudantes e professores, a escassa disponibilidade de materiais que explorem a interface físico-musical, e a tradição de tratar a música como tema secundário dentre as muitas implicações da ondulatória. Desta forma, pretende-se investigar as potencialidades que o tratamento desta temática pode trazer ao ensino da física. 


\subsection{Objetivos do trabalho}

- Reunir contribuições históricas necessárias à compreensão da relação entre física, matemática e música no Renascimento.

- Extrair de registros históricos pertinentes, indicadores da presença da verificação experimental na produção de conhecimento acústico durante o Renascimento.

- Como parte do trabalho de campo, abordar, por meio da exposição didática no museu Estação Ciência, fenômenos relevantes para a compreensão racional da acústica musical renascentista.

- Discutir estratégias de ensino sobre o desenvolvimento da relação entre física, matemática e música à luz de conceitos epistemológicos concebidos pelo filósofo da ciência Thomas Kuhn.

\subsection{Pressupostos básicos e a metodologia de pesquisa}

Da perspectiva metodológica esta pesquisa envolveu encontros periódicos com o orientador e com o grupo de pesquisa que visavam estabelecer uma bibliografia básica, que fornecesse subsídios historiográficos para sustentar a hipótese de que a Acústica Musical, assim como a Gravitação Universal, foram objetos, no Renascimento, da Revolução Científica, isto é, passaram de um paradigma essencialmente baseado em um dogmatismo aritmético para um novo paradigma sustentado pela valorização do experimento.

Como fundamento teórico desta pesquisa será explorado o projeto epistemológico de Thomas Kuhn, assim a obra "A estrutura das Revoluções Científicas" será uma das referências amplamente exploradas neste texto, de tal forma que deve-se atribuir um significado Kuhniano na leitura desta dissertação para os termos paradigma, crise epistemológica e Revolução Científica. 
É pressuposto que o leitor deste material não é um músico proficiente. Assim, sempre que a teoria musical for abordada a dissertação buscará fornecer subsídios para que um leigo possa entender esta discussão.

\section{$1.4 O$ ensino da relação entre a física e a música}

O estudo da ondulatória, ou mesmo da acústica muitas vezes pouco exploram as relações entre a física e a música. Entretanto, esta dissertação tem a pretensão de evidenciar que o trabalho com este conteúdo propicia não só um aprofundamento na análise de um dos elementos mais importantes de nossa cultura, bem como possibilita aprofundar habilidades, competências e conteúdos imprescindíveis para um estudante de física. Além disso, um olhar cuidadoso para o desenvolvimento histórico desta estrutura conceitual permite que os estudantes contemplem importantes elementos de como se faz e se fez ciência ao longo da história.

Neste sentido, o tratamento deste conteúdo permite que muitos dos principais objetivos de um curso de física sejam abordados. Além disso, o conteúdo por si só pode motivar estudantes já interessados por música, e possibilitar um rico trabalho com instrumentos musicais do cotidiano dos alunos e propiciando assim uma ampla discussão sobre elementos da música e dos instrumentos típicos de cada região.

\subsection{Física e cultura}

Os trabalhos do professor doutor João Zanetic da Universidade de São Paulo têm apontado na direção de integrar o conhecimento físico com elementos da cultura popular.

Entre o tratamento de poesias e da música popular brasileira foi se explorando a necessidade de uma integração maior entre o ensino de física e elementos de nossa cultura. 
É indiscutível que a música integra parte fundamental de nossa cultura, e neste sentido, este trabalho tem a pretensão de explicitar um enfoque para o olhar do ensino de acústica.

Assim, a exploração do funcionamento dos instrumentos musicais, assim como o olhar para a história da acústica revelam-se como estratégias importantes para o tratamento deste assunto. Sabe-se que ao ensinar física opera-se com um conjunto de "caixas pretas", entretanto lidar com este conteúdo pode propiciar condições para abrir uma série destas "caixas", contribuindo assim para a construção de uma concepção de ciência mais ampla e menos dogmática por parte dos alunos.

\subsection{Conceitos introdutórios de música}

Visto que este material tem a pretensão de discutir o ensino de física, sua estrutura está pensada visando atender principalmente os professores de física. Assim, foi pressuposto que os conceitos musicais envolvidos na compreensão do texto deverão ser explicitamente discutidos. Para isto, esta seção do texto trará uma discussão sobre conceitos básicos da teoria musical que de alguma maneira serão abordados neste ou nos próximos capítulos. Além disso, foi elaborado um glossário físico-musical (no final desta dissertação) visando colaborar com a leitura deste texto.

\subsubsection{Intervalos Musicais}

Intervalo musical é a medida da "distância" entre duas alturas musicais (notas). Naturalmente, como em qualquer medida de "distância", é preciso tomar uma nota como referência e a partir dela as distâncias ganharam uma nomenclatura específica utilizada 
pelos músicos. Segue abaixo uma tabela que representa a nomenclatura específica e dois exemplos tomando as notas dó e lá como referência:

\begin{tabular}{|c|c|c|c|}
\hline $\begin{array}{l}\text { Símbolo dos } \\
\text { Intervalos }\end{array}$ & $\begin{array}{l}\text { Nome dos } \\
\text { Intervalos }\end{array}$ & $\begin{array}{c}\text { Exemplo } \\
\text { (Tomando a nota } \\
\text { dó como } \\
\text { referencia ) } \\
\end{array}$ & $\begin{array}{c}\text { Exemplo } \\
\text { (Tomando a nota } \\
\text { lá como } \\
\text { referencia) } \\
\end{array}$ \\
\hline $\mathrm{T}$ & Tônica & DÓ & LÁ \\
\hline $2 \mathrm{~b}$ & Segunda Menor & DÓ\# & LÁ\# \\
\hline 2 & Segunda Maior & RÉ & SI \\
\hline $3 b$ & Terça Menor & RÉ\# & DÓ \\
\hline 3 & Terça Maior & MI & DÓ\# \\
\hline 4 & Quarta Justa & FÁ & RÉ \\
\hline $4 \#$ & $\begin{array}{l}\text { Quarta } \\
\text { Aumentada }\end{array}$ & FÁ\# & RÉ\# \\
\hline 5 & Quinta & SOL & MI \\
\hline $6 \mathrm{~b}$ & Sexta Menor & SOL\# & FÁ \\
\hline 6 & Sexta Maior & LÁ & FÁ\# \\
\hline $7 \mathrm{~b}$ & Sétima Menor & LÁ\# & SOL \\
\hline 7 & Sétima Maior & SI & SOL\# \\
\hline 8 & Oitava & DÓ & LÁ \\
\hline
\end{tabular}

Tabela 1: Intervalos musicais de uma oitava completa.

Note que a construção da tabela é relativamente simples, basta conhecer a nomenclatura apresentada e a escala cromática, isto é, o conjunto de todas as notas que 
conhecemos aumentando de meio em meio tom ${ }^{2}$. Vale ressaltar que a escala cromática é composta pelas sete notas naturais ( dó, ré, mi, fá, sol, lá e si ) acrescida de seus acidentes (dó\#, ré\#, fá\#, sol\# e lá\# - não há nem si, nem mi sustenidos) compondo assim uma escala de doze notas. É possível iniciar a tabela por qualquer nota, assim pode-se dizer que a terça maior de dó é sol, ou que a sexta maior de dó é lá, mas também pode-se afirmar que a terça maior de sol é si.

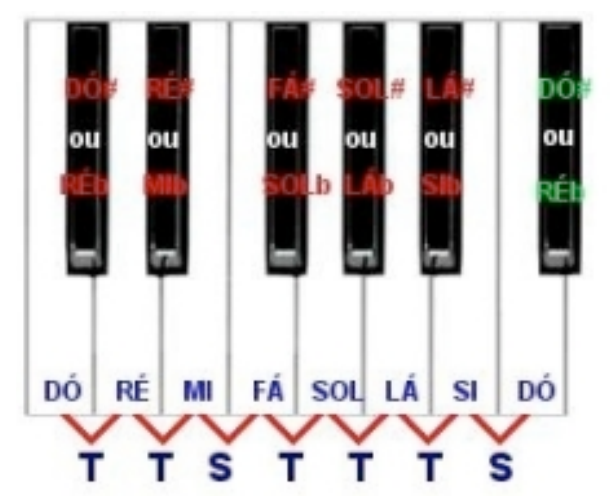

Figura 1: Uma oitava de um piano representando a escala cromática.

Obs.: A notação T representa um intervalo de 1 tom e a letra $\mathrm{S}$ um semitom ( meio tom).

\subsubsection{Notas e Acordes: Um estudo de harmonia}

A música é formada essencialmente por harmonia, melodia e ritmo. A principal diferença entre a harmonia e a melodia é que a melodia é composta por um conjunto de notas tocadas serialmente, isto é, uma nota por vez, enquanto que na harmonia toca-se um conjunto de notas simultaneamente formando acordes.

Da perspectiva da física pode-se associar a altura musical à sua freqüência. Assim, quanto mais agudo é um som maior é sua freqüência. Entretanto cada vez que se dobra uma

\footnotetext{
${ }^{2}$ Note que na tabela o avanço de cada linha representa o aumento de meio tom (ou de um semitom).
} 
freqüência escuta-se a mesma nota oitavada. Segue abaixo um conjunto de notas associadas às suas respectivas freqüências no temperamento igual.

$$
\begin{aligned}
& \text { Lá }-440 \mathrm{~Hz} \\
& \mathrm{Si}-493,88 \mathrm{~Hz} \\
& \text { Dó }-523,25 \mathrm{~Hz} \\
& \text { Ré- } 587,33 \mathrm{~Hz} \\
& \mathrm{Mi}-659,25 \mathrm{~Hz} \\
& \text { Fá }-698,46 \mathrm{~Hz} \\
& \text { Sol }-783,99 \mathrm{~Hz}
\end{aligned}
$$

Os acordes são conjuntos de notas. Assim sempre que um músico fala em acorde maior ou menor ele se refere à terça ser maior ou menor. Desta forma a formação de acordes respeita uma nomenclatura que permite a qualquer músico de posse do nome de um acorde saber quais são as notas que o formam. Por exemplo:

Um acorde maior é composto por tônica + terça maior + quinta. Assim quando um músico fala em um dó maior ele se refere a um conjunto de notas formado por dó + mi (terça maior de dó) + sol (quinta de dó). É comum que se represente as notas com letras maiúsculas do alfabeto de acordo com a notação abaixo:

$$
\begin{aligned}
& \text { A-Lá } \\
& \text { B-Si } \\
& \text { C- Dó } \\
& \text { D-Ré } \\
& \text { E-Mi } \\
& \text { F- Fá }
\end{aligned}
$$


$\mathrm{G}-\mathrm{Sol}$

Assim segue alguns exemplos de formação de acordes:

C7M: C (T) $+\mathrm{E}(3)+\mathrm{G}(5)+\mathrm{B}(7)$

$\mathrm{Cm}: \mathrm{C}(\mathrm{T})+\mathrm{D} \#(3 \mathrm{~b})+\mathrm{G}(5)$

$\mathrm{C}: \mathrm{C}(\mathrm{T})+\mathrm{E}(3)+\mathrm{G}(5)$

Gm7: G (T) +A\#(3b) + D (5) + F (7b)

Em música, Harmonia é o estudo das relações de encadeamento de acordes (conjunto de notas tocadas simultaneamente). Tradicionalmente, obedece a uma série de normas que se originam nos processos composicionais efetivamente praticados pelos compositores da tradição européia, entre o período do fim da Renascença ao início do século XX.

\subsubsection{Consonâncias e dissonâncias}

Ao longo da história da música muitos intervalos musicais foram considerados consonantes ou dissonantes. Pode-se dizer que o conceito de consonância está associado à idéia de conforto e assim sugere uma tendência de repouso, ao passo que o conceito de dissonância está associado a um desconforto que sugere a necessidade do movimento.

Uma importante questão a ser discutida neste trabalho diz respeito à relação entre a física e os sons consonantes e dissonantes, assim a investigação sobre as razões físicas e psicofísicas que levam um som a ser mais ou menos consonante serão amplamente discutidas neste texto.

Para isso faz-se necessária uma breve reflexão sobre o que é consonância. Neste sentido segue abaixo uma definição: 
“ Na harmonia tradicional, uma consonância (do latim consonare, significando soar junto) é uma harmonia, um acorde ou um intervalo considerado estável, em relação a uma dissonância que é considerada instável. Em uma definição mais restritiva a consonância pode ser um conjunto de vibrações sonoras concordantes e portanto aceitas como mais confortáveis ao ouvido em oposição às dissonâncias (grupo de duas ou mais notas que criam forte tensão e se tornam instáveis ao ouvido, que por natureza busca a resolução em acordes consonantes)."(HENRIQUE DOURADO)

Ao longo da história, muitos físicos e matemáticos buscaram explicar por que um som é consonante ou dissonante entre eles destacam-se: Pitágoras, Zarlino, Descartes, Galileu Galilei, Helmholtz, entre outros... No próximo capítulo discutiremos alguns dos critérios que estes pensadores utilizaram para delimitar este conceito. 


\section{CAPÍTULO 2 \\ A FÍSICA DA MÚSICA: DOS GREGOS À MÚSICA CONTEMPORÂNEA}

\subsection{O Monocórdio e suas consequências}

O experimento do monocórdio é o primeiro registro histórico da relação entre a música e a física/matemática. Essencialmente o experimento consiste em esticar uma corda e ao variar seu comprimento pode-se associar intervalos musicais ao comprimento da corda.

A realização deste experimento permitiu que as razões de comprimento da corda 1:2, 2:3 e 3:4 fossem associadas aos intervalos musicais de oitava, quinta e quarta respectivamente. Além disso, o experimento reforçava um dogmatismo aritmético presente na estrutura da tradição pitagórica, no qual acreditava-se que as leis da natureza poderiam ser sistematizadas como os quatro primeiros números inteiros (1, 2, 3 e 4).

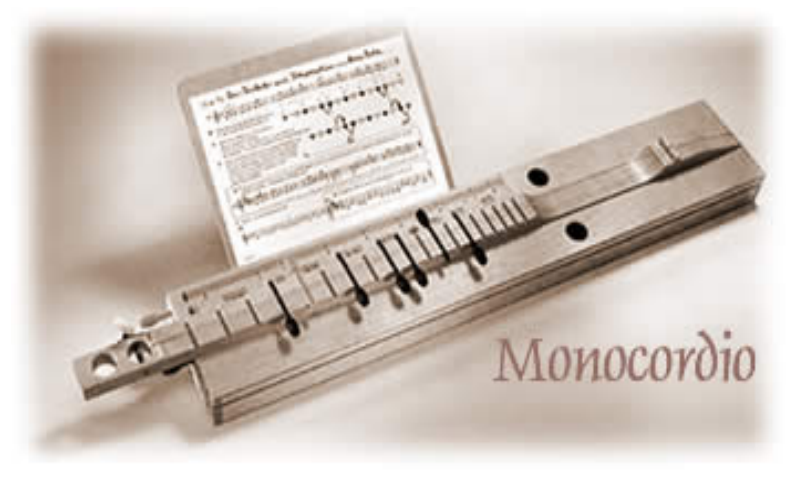

Figura 2: $\quad$ O Monocórdio

Tal dogmatismo aritmético ganhou tamanha importância que o filósofo inglês Robert Fludd (1574-1637) fez a imagem apresentada abaixo, onde Deus toca um grande monocórdio no qual o mundo está inserido. Alguns séculos depois Kepler vai sistematizar o som dos planetas reforçando a importância da doutrina pitagórica no universo científico. 


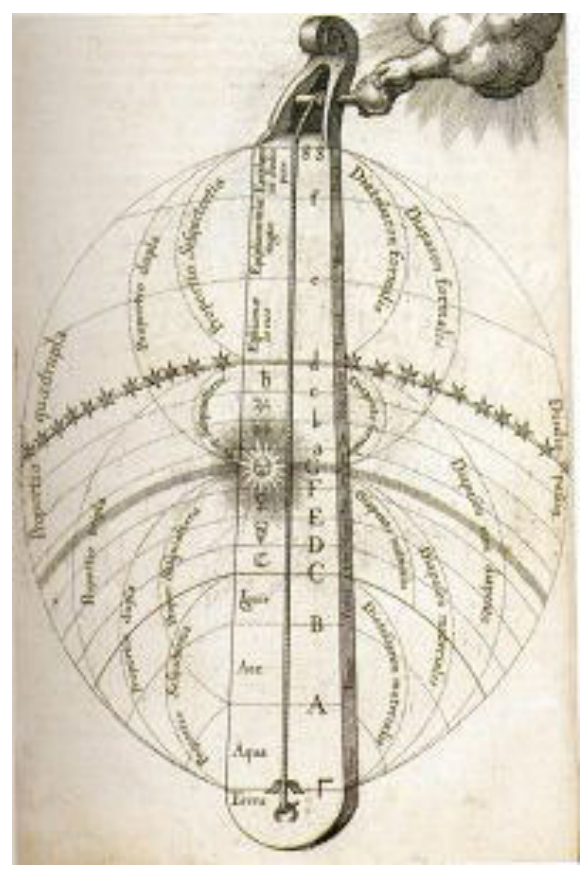

Figura 3: O Divino Monocórdio, de Robert Fludd.

No Divino Monocórdio de Fludd a nota correspondente a cada planeta é associada a uma divisão da corda do monocórdio.

Na tradição Pitagórica, esse resultado generalizou-se para diferentes fontes acústicas com base num simbolismo numérico. Um exemplo interessante de tal força do dogmatismo aritmético se reflete ainda em teóricos do século XV como no caso de Franchino Gaffurio. No capítulo chamado "A investigação e descoberta das consonâncias musicais" de seu Theoretica musice de 1492, Gaffurio apresenta graficamente a história de Boécio sobre o experimento de Pitágoras no monocórdio -- que resultou para a corda na relação entre as razões 1:2, 2:3 e 3:4 e os intervalos musicais de oitava, quinta e quarta respectivamente --, agora generalizada para outras fontes sonoras tais como copos, sinos, flautas etc. 


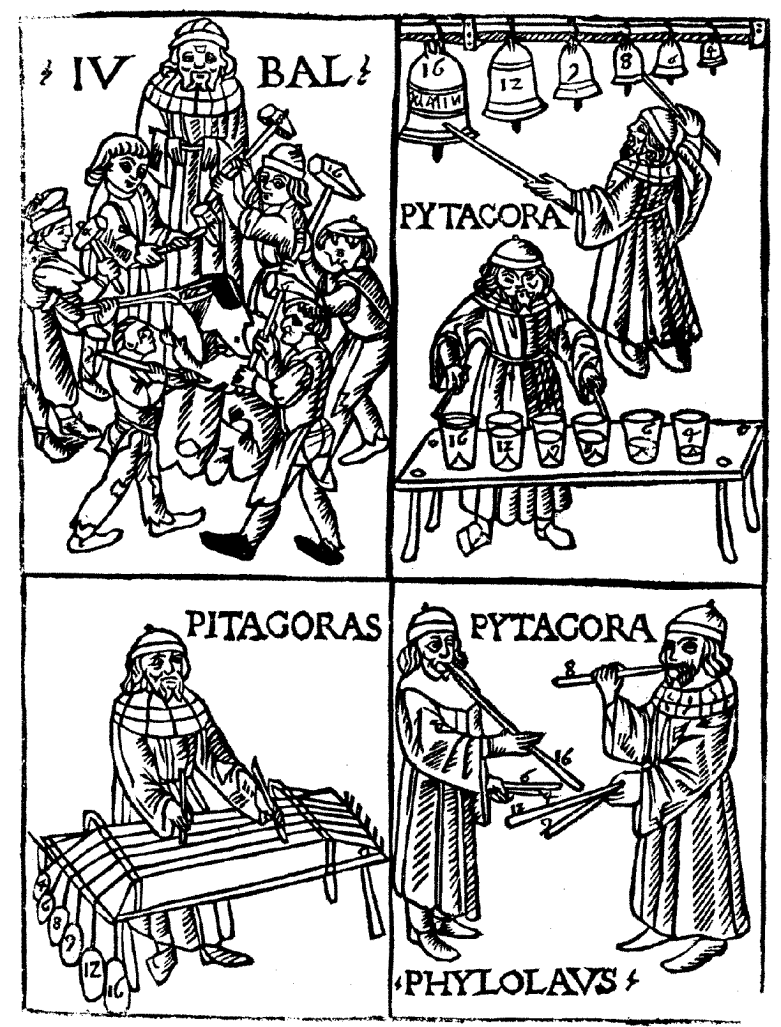

Figura 4: Imagem concebida por Franchino Gaffurio que mostra a generalidade da tradição pitagórica.

Dentre as limitações do sistema musical pitagórico destacam-se:

1) A rígida distinção entre consonância e dissonância, a utilização somente de razões comensuráveis, ou anacronicamente, números racionais na expressão de intervalos musicais.

2) A inferência de que os resultados encontrados para a corda valiam em qualquer outro sistema físico que emitisse som (copos com água, sinos, etc...Como mostra a representação do Gaffurio).

Tais limitações são fortemente representativas da doutrina pitagórica segundo a qual todo o conhecimento reduzir-se-ia a relações numéricas, onde número nesse contexto significa número inteiro. 
Tal experimento informa não somente que às consonâncias perfeitas $8^{\mathrm{a}}, 5^{\mathrm{a}}$ e $4^{\mathrm{a}}$ subjazem razões simples 1:2, 2:3 e 3:4, mas ainda que à composição de intervalos musicais subjaz a composição de razões matemáticas, fundamento da construção da escala pitagórica. Em outras palavras, um importante legado do experimento de Pitágoras consiste na percepção de que subir ou descer um intervalo musical corresponde respectivamente a compor ou decompor o comprimento da corda produtor da nota mais grave ou mais aguda pelo fator correspondente ao intervalo referido.

O critério pitagórico para construção de escala resulta na obtenção de quintas compostas reduzidas posteriormente a notas equivalentes na oitava, ou seja, supondo que uma nota inicial dó é produzida por 1 , sua quinta será produzida por 2:3, equivalente à nota sol. A quinta do sol, por sua vez, por $(2: 3)(2: 3)=(4: 9)$, que reduzido à oitava original resulta em 8:9, equivalente à nota ré. A quinta de ré será produzida por $(8: 9)(2: 3)=16: 27$, que equivale à nota lá, e assim por diante, resultando na seguinte escala diatônica:

$$
\begin{aligned}
& \text { Segunda }=1 \text { Quinta }+1 \text { quinta }-1 \text { oitava }=\frac{\frac{2}{3} \cdot \frac{2}{3}}{\frac{1}{2}}=\frac{8}{9} \\
& \text { Terça }=1 \text { Sexta }+1 \text { Quinta }-1 \text { Oitava }=\frac{\frac{16}{27} \cdot \frac{2}{3}}{\frac{1}{2}}=\frac{64}{31} \\
& \text { Quarta }=\frac{3}{4} \text { (Monocórdio) } \\
& \text { Quinta }=\frac{2}{3} \text { (Monocórdio) }
\end{aligned}
$$




$$
\begin{aligned}
& \text { Sexta }=1 \text { Segunda }+1 \text { Quinta }=\frac{8}{9} \cdot \frac{2}{3}=\frac{16}{27} \\
& \text { Sétima }=1 \text { Sexta }+1 \text { Segunda }=\frac{16}{27} \cdot \frac{8}{9}=\frac{128}{243} \\
& \text { dó ré mi fá sol lá si dó } \\
& \begin{array}{llllllll}
1 & 8: 9 & 64: 81 & 3: 4 & 2: 3 & 16: 27 & 128: 243 & 1: 2
\end{array}
\end{aligned}
$$

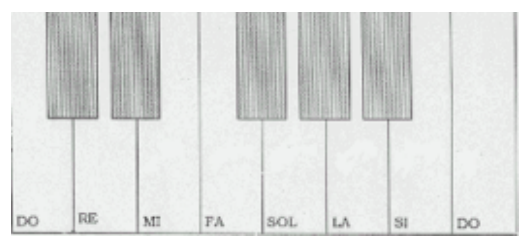

Figura 5: A escala diatônica representada no piano.

Os pitagóricos justificaram a subjacência de pequenos números inteiros às consonâncias pelo fato de que os números 1,2, 3 e 4 geravam toda a perfeição, na medida em que consideravam o número quatro como a origem de todo o universo, todo o mundo material, representando a matéria em seus quatro elementos: o fogo, o ar, a terra e a água.

A tradição musical pitagórica foi transmitida para a Idade Média principalmente através do tratado De Institutione musica, escrito no início do século VI d.C. por Boécio (475-524). Tal obra influenciou a grande maioria de tratados teórico-musicais da Idade Média determinando a predominância do pitagorismo na música teórica medieval e como consequência uma abordagem matemático-especulativa como base teórica para resolução dos problemas teórico-musicais.

\subsection{A crítica ao pensamento pitagórico e o nascimento de uma nova ciência}

As relações entre comprimentos da corda e intervalos musicais estabelecidas pelos pitagóricos vigoraram de forma generalizada até que Vincenzo Galilei (1520-1591) as 
criticasse mostrando que tais relações variavam não somente segundo o parâmetro medido na corda -- tensão, densidade linear, etc. --, mas de maneira geral, segundo o parâmetro medido em qualquer fonte sonora. Intensificada no decorrer do século XVII, tal perspectiva físico-experimental representa a semente de uma mudança significativa de enfoque sobre a compreensão de conceitos acústico-musicais tais como consonância, Série Harmônica, etc.

A crítica de Vincenzo Galilei é representativa de um novo paradigma científico, no qual o dogmatismo aritmético presente na tradição pitagórica é substituído por uma prática científica vinculada à análise experimental. Esta mudança paradigmática no desenvolvimento científico é um dos aspectos que esta pesquisa visa evidenciar, a partir da extração, de fontes historiográficas, de elementos indicadores da valorização da experiência na ciência musical, tal como a crítica de Vincenzo Galilei à generalização dos resultados do monocórdio sem base experimental.

Assim o Renascimento mostra-se um período de grande relevância histórica, pois além das diversas transformações no âmbito das artes, da filosofia e da relação do homem com o conhecimento, neste período foi concebida uma nova maneira de fazer ciência, sobretudo no que se refere ao papel do experimento no procedimento científico.

Desta forma, a acústica musical nasce como uma ciência experimental, e desta forma as concepções pitagóricas são gradativamente substituídas por novos modelos teóricos embasados experimentalmente.

No século XVII o desenvolvimento da acústica deu um salto qualitativo na medida que a visão da ciência mudou sua perspectiva, deixando mais de lado os dogmas aritméticos e dando mais enfoque as evidências experimentais. 


\subsection{O temperamento igual e outros temperamentos}

Com a emergência da Polifonia (melodias tocadas simultaneamente) surgem problemas entre teoria e prática, cujas pretensões exigiam uma fundamentação teórica incongruente com os pressupostos pitagóricos, segundo os quais consonâncias musicais eram geradas por razões entre os números 1, 2, 3 e 4 e intervalos musicais somente por razões comensuráveis. De fato, o próprio experimento do monocórdio, que revela que os intervalos de quinta e oitava estão relacionados respectivamente com razões $2: 3$ e 1:2, já contém potencialmente o problema levantado pelo advento da Polifonia na medida em que a partir de seus resultados, constata-se que não existem $m$ e $n$, inteiros positivos tais que $(2 / 3)^{\mathrm{m}}$ seja igual a $(1 / 2)^{\mathrm{n}}$, o que implica na impossibilidade de encaixar um número inteiro de ciclos de quintas em um número inteiro de ciclos de oitavas.

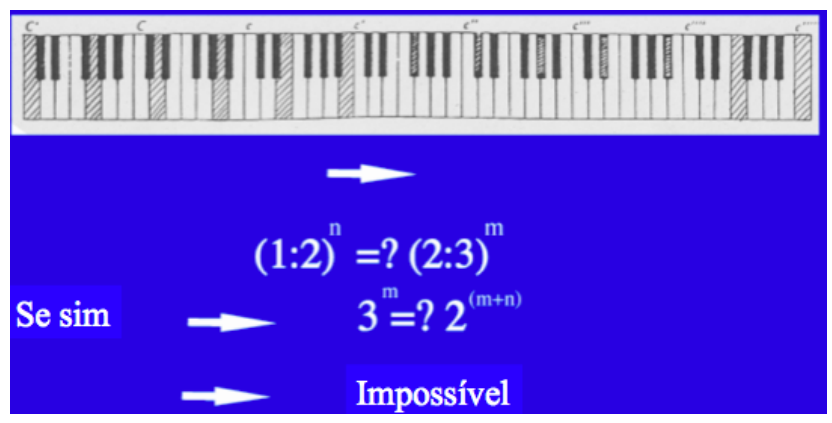

Figura 6: O problema do ciclo de quintas.

Tal impossibilidade resultaria na coma pitagórica, que representa a "semente da imperfeição", de natureza semelhante à irracionalidade na matemática e impossibilidade de ajuste preciso entre ciclos naturais da Lua e da Terra em torno do Sol na astronomia. Ou seja, podemos dizer que os doze semitons não "cabem” exatamente em uma oitava, assim como 12 meses de trinta dias não “cabem” exatamente no ano de 365 dias. Desse modo, tanto no calendário quanto na teoria musical, simetria e pureza são impossíveis, de tal forma que ou sistematizamos o semitom diferente da experiência de Pitágoras, sendo assim 
todos os intervalos musicais impuros, ou criamos um intervalo assimétrico, com semitons variando de tamanho. A percepção de tal problema é completamente análoga ao problema dos calendários, ou seja, ou desrespeitamos o ciclo lunar de aproximadamente 30 dias, ou criamos onze meses de trinta dias (portanto, puros) e um mês de trinta e cinco dias (portanto assimétrico). Tais observações estabeleceriam uma melhor compreensão da discussão sobre a relação entre o advento da Polifonia e a necessidade de um Temperamento, uma vez que a coma pitagórica e as outras geradas a partir das tentativas de construção de escalas musicais baseadas em números racionais representam o motor para o desenvolvimento dos diversos temperamentos.

Uma possível solução para este problema é o Temperamento Igual, que tem como característica fundamental o fato da relação matemática entre as frequências de notas de um mesmo intervalo ser sempre igual, ou seja, a razões entre as frequências de duas notas distantes uma da outra de um semitom é sempre a mesma, não importando quais duas notas sejam (ex: dó e dó\# e ou dó e dó bemol ou sol e sol\#) -- o que implica que fá\# e sol bemol por exemplo são equivalentes.

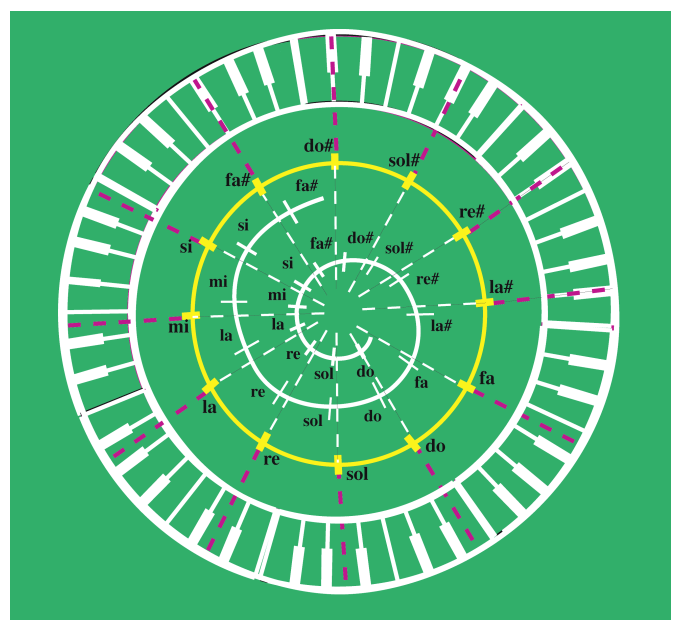

Figura 7: Imagem produzida pelo prof. Dr. Oscar João Abdounur para representar o temperamento igual. 
Em outras palavras o Temperamento Igual consiste em dividir a oitava em 12 partes iguais, o que resulta no encontro entre 12 ciclos de quinta e 7 ciclos de oitava. Neste caso, a razão relacionada ao intervalo de quinta seria $1: 2^{7 / 12}$, que numericamente é aproximadamente 1,4983, e não 1,5 correspondente à razão 3:2 como propunha Pitágoras. Dado a importância do temperamento igual na música teórica, tal tratamento torna-se imprescindível para a compreensão da acústica musical. Além disso, no âmbito desta pesquisa tal conceito mostra-se fundamental a medida que aproxima a música teórica da música prática, denotando desta forma a necessidade de validar o experimento como parte essencial do desenvolvimento científico.

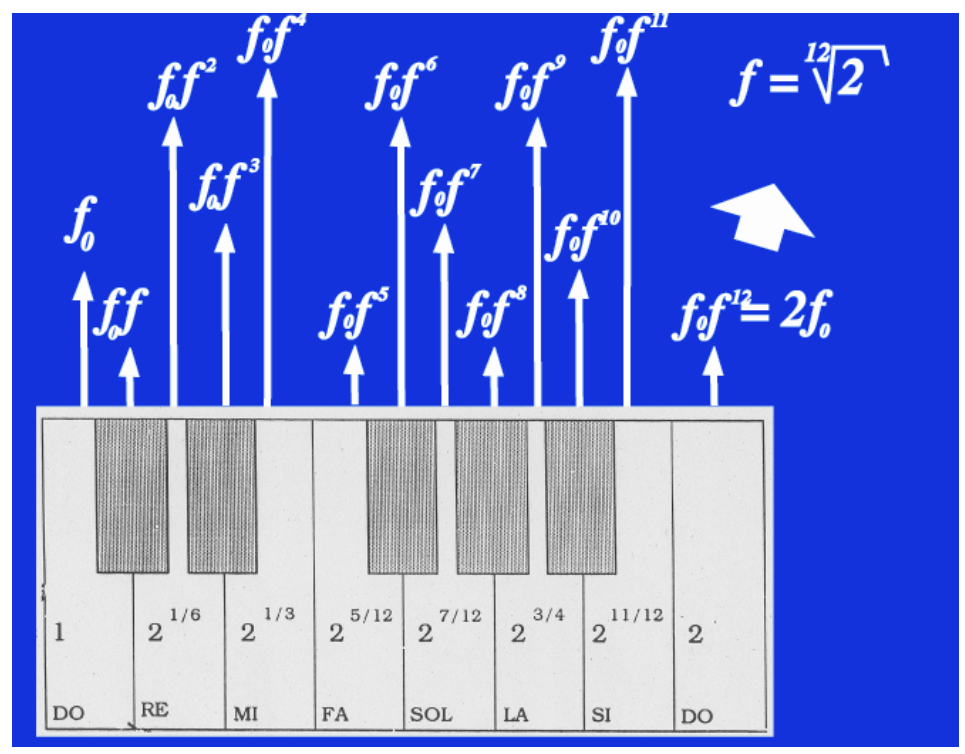

Figura 8: Fundamentando o temperamento igual

Vale ainda ressaltar que o temperamento igual foi uma das diversas soluções para este problema, e ao longo da história outros tipos de temperamento foram criados. 


\subsection{As cordas vibrantes, seus modos de vibração, o princípio de Superposição e a}

\section{Série Harmônica}

No século XVII físicos e matemáticos começaram a dar mais atenção ao tema, tais como Marin Mersenne (1588-1648), John Wallis (1616-1703), Johannes Kepler (15711630), Vincenzo Galilei, Galileu Galilei (1554-1642), René Descartes (1596-1650), Christiaan Huygens (1629-1695), Joseph Saveur (1653-1716), Isaac Newton(1642-1727), entre outros.

Com o trabalho destes cientistas a acústica passou a apresentar fundamentação empírica, inicialmente com Mersenne que além de estabelecer, juntamente com Galileu, a lei de Mersenne-Galileu -- em uma corda vibrante, a frequência é inversamente proporcional ao comprimento de corda, é proporcional à raiz quadrada da tensão e inversamente proporcional à raiz quadrada da densidade linear da corda --, começou a relacionar diretamente a altura de uma nota emitida por uma fonte com sua frequência de vibração. Isso dava início a uma resposta ao problema proposto por Vincenzo Galilei, que mostrava a insuficiência de razões de números sem base experimental para a determinação de intervalos musicais, como propunham os pitagóricos.

$$
\mathrm{f}_{n}=\frac{n}{2 L} \sqrt{\frac{T}{\mu}}
$$

Fórmula de Mersenne- Galileu: em que n é o número do modo de vibração da corda, L é seu comprimento, T a tensão que esta está submetida e $\mu$ sua densidade linear.

Ainda no século XVII, Mersenne levantou um novo paradoxo que consistia em saber se um mesmo objeto poderia vibrar em várias frequências simultaneamente. Tal paradoxo só pôde ser resolvido no final desse século quando Joseph Saveur propôs o 
Princípio da Superposição. Ao mesmo tempo, esse problema motivou a busca de explicações para o conceito de Série Harmônica. Mais tarde o conceito de Série Harmônica tornou-se fundamental para diferenciar timbres.

Produzir um som em um instrumento musical significa colocar algum elemento em que esta vibração seja transmitida ao ar. A frequência ou altura do som produzido vai depender das características do meio vibratório (uma corda, coluna de ar, etc); os sistemas físicos não vão vibrar de uma única forma, mas sim emitindo diversas frequências, todas múltiplas da nota fundamental. Estas outras frequências são os harmônicos ou parciais, e sua composição (Série Harmônica) é o que vai caracterizar o timbre do instrumento.

Por volta de 1673, Christiaan Huygens, influenciado por Mersenne, adquiriu interesse por harmônicos. Ele estimou frequências absolutas e estabeleceu a relação entre comprimento de onda e comprimento da corda. Em 1677, o matemático John Wallis publicou um artigo mostrando experimentalmente que os harmônicos gerados por uma corda estavam relacionados com seus nós.

No início do século XVIII, Joseph Saveur propôs o início de uma nova ciência que se poderia chamar acústica. Ele mostrou que um mesmo objeto pode produzir diferentes freqüências simultaneamente, o que o levou a conceber o Princípio da Superposição para ondas sonoras. O Princípio da Superposição consiste em dizer que a forma de onda representante da emissão de dois ou mais sons simultaneamente é a soma das formas de onda representantes de cada um dos sons envolvidos. Particularmente, a frequência de uma nota dada é a superposição de cada um de seus harmônicos.

Em 1677 John Wallis realizou um simples experimento que evidenciou o comportamento das cordas vibrantes, assim pôde-se estabelecer que uma corda vibrante tem diversos modos de vibração e que cada modo de vibração produz um som diferente. 
Desta forma pode-se concluir que ao vibrar uma corda não produz apenas uma frequência, mas sim todos os múltiplos inteiros da frequência de seu primeiro modo de vibração ( quando os nós estão nas extremidades da corda).

\subsection{O timbre visto a partir da relação entre a Série Harmônica e a Série de Fourier}

Assim, do ponto de vista físico é possível afirmar que, ao oscilar, uma corda produz diversos sons, cada um desses sons são chamados de harmônicos e o conjunto deles é a Série Harmônica. Vale ressaltar que outros tipos de fontes sonoras também podem apresentar diversos modos de vibração e portanto produzem diversos harmônicos. A relação entre a amplitude destes harmônicos definem o timbre do som.

Do ponto de vista matemático pode-se afirmar que a Série de Fourier é uma maneira de obter as componentes de uma onda complexa separando seus harmônicos. Sendo assim, há uma estreita relação entre a Série Harmônica e a Série de Fourier. Tal relação mostra-se um conceito essencial para a compreensão do timbre, já que essencialmente o que diferencia o timbre de diversos instrumentos musicais é a amplitude de seus harmônicos.

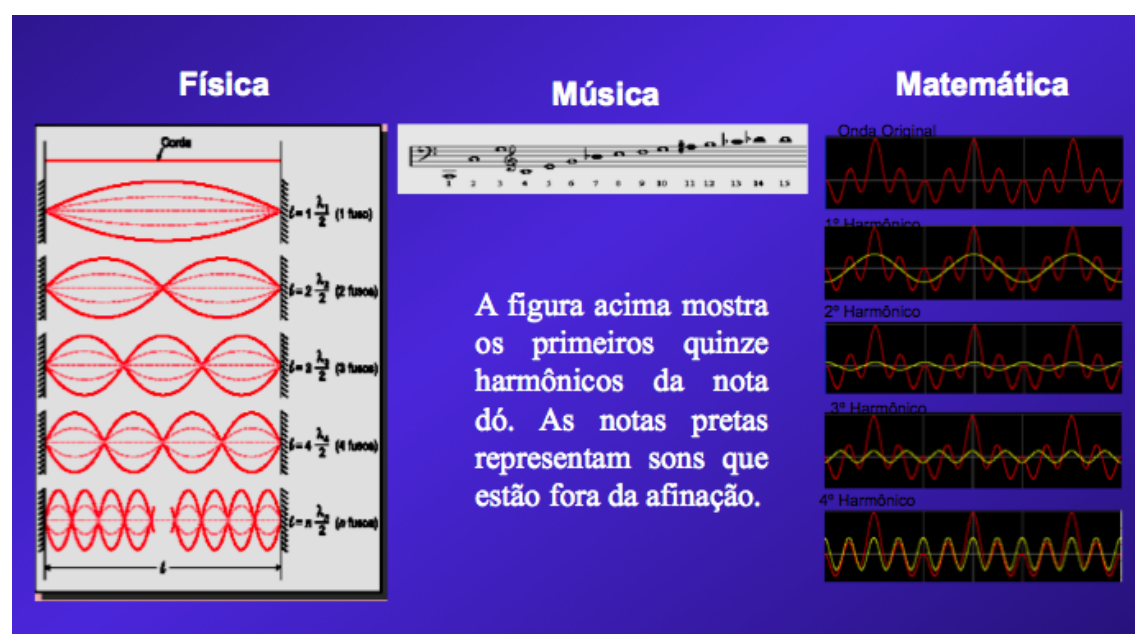

Figura 9: A relação entre os modos de vibração da corda, a Série Harmônica e a Série de Fourier 
Neste sentido para que seja construída de maneira clara a relação entre os fenômenos físicos envolvidos quando um instrumento é tocado, é fundamental que se entenda como este instrumento amplifica o som (ressonância, amplificação elétrica...), como o instrumento vibra, ou seja, quais são os modos de vibração que geram harmônicos com maior amplitude ( e portanto qual será seu timbre) e como este instrumento é afinado (batimento , fórmula de Mersenne-Galileu).

\subsection{Análises sobre o conceito de consonância}

Historicamente a discussão sobre como diferenciar se um som era consonante ou dissonante mostrou-se de grande relevância para o fazer musical. Para isso, é fundamental evidenciar como este conceito se construiu com o passar do tempo.

Vale ressaltar que uma discussão pertinente sobre tal conceito deve ser considerada: consonância é um conceito físico, cultural ou fisiológico? Particularmente neste trabalho considera-se que os três aspectos devem ser levados em consideração, e neste sentido pretende-se organizar diferentes concepções sobre o conceito apresentado ao longo da história da acústica.

Considerando os aspectos matemático-acústicos dos conceitos de consonância/dissonância, segue abaixo diferentes concepções físico-matemáticas de consonância construídas no decorrer da história:

- $\quad$ razão de números simples (1,2, 3 e 4) por Pitágoras;

- $\quad$ Emissão de duas ou mais notas que soam como uma por Arquitas (Fallas, 1992);

- Coincidência de harmônicos de duas ou mais notas por Zarlino associada diretamente ao MMC entre suas frequências (Abdounur, 1999, p.211); 
- Coincidência das pulsações geradoras das notas em questão por Galileu (Cohen, 1984, p.90);

- Proximidade da raiz harmônica na Série de Fourier; concepção fisiológica de Helmholtz (Helmholtz, 1954) etc.

Visando uma análise do número de harmônicos que coincidem em cada intervalo, ou seja, ao tocarmos duas notas simultâneas todos seus harmônicos soam simultaneamente, podendo coincidir alguns harmônicos, este trabalho analisou o número de harmônicos que coincidem em cada intervalo musical, podendo desta forma apresentar uma interpretação para a consonância. Para facilitar tal análise segue uma tabela que contém a série harmônica associada a cada nota.

\begin{tabular}{|c|c|c|c|c|c|c|c|c|}
\hline Série Harmônica & 1 & 2 & 3 & 4 & 5 & 6 & 7 & 8 \\
\hline Tônica & Dó & Dó & Sol & Dó & Mi & Sol & Sib & Dó \\
\hline Segunda menor & Dó\# & Dó\# & Sol\# & Dó\# & Fá & Sol\# & Si & Dó\# \\
\hline Segunda & Ré & Ré & Lá & Ré & Fá\# & Lá & Dó & Ré \\
\hline Terça Menor & Ré\# & Ré\# & Lá\# & Ré\# & Sol & Lá\# & Dó\# & Ré\# \\
\hline Terça & Mi & Mi & Si & Mi & Sol\# & Si & Ré & Mi \\
\hline Quarta Justa & Fá & Fá & Dó & Fá & Lá & Dó & Ré\# & Fá \\
\hline Quarta Aumentada & Fá\# & Fá\# & Dó\# & Fá\# & Lá\# & Dó\# & Mi & Fá\# \\
\hline Quinta & Sol & Sol & Ré & Sol & Si & Ré & Fá & Sol \\
\hline Sexta Menor & Sol\# & Sol\# & Ré\# & Sol\# & Dó & Ré\# & Fá\# & Sol\# \\
\hline Sexta & Lá & Lá & Mi & Lá & Dó\# & Mi & Sol & Lá \\
\hline Sétima Menor & Lá\# & Lá\# & Fá & Lá\# & Ré & Fá & Sol\# & Lá\# \\
\hline Sétima & Si & Si & Fá\# & Si & Ré\# & Fá\# & Lá & Si \\
\hline Oitava & Dó & Dó & Sol & Dó & Mi & Sol & Sib & Dó \\
\hline
\end{tabular}

$\mathrm{b}=$ Bemol

\#=Sustenido

Tabela 2: Intervalos com cada harmônico da nota

Como foi dito anteriormente, a tabela acima foi utilizada para analisar os conceitos de consonância/dissonância, porém para fazer uma análise consistente faz-se necessário uma explicação de tais conceitos. A consonância é definida hoje como sendo um som que causa uma sensação de repouso, em função de uma fusão entre as notas. Existem três tipos 
de consonância: a consonância perfeita (quinta e oitava), consonância mista (quarta justa) e consonância imperfeita (terças (maior e menor) e sextas (maior e menor)). O restante dos intervalos musicais são considerados dissonantes (movimento das notas não se fundem).

Resumindo, consonância e dissonância são sensações subjetivas associadas a dois ou mais sons soando simultaneamente, todavia a música tonal indica que o sistema auditivo humano possui um senso para certos intervalos especiais de freqüência - a oitava, a quinta, a quarta etc. $\mathrm{O}$ mais significativo é que estes intervalos são avaliados quase na mesma ordem em que eles aparecem na série harmônica.

Analisando a tabela percebe-se que quando os sons complexos soam em uníssono ou oitava perfeitamente afinados, todos os harmônicos de uma nota casarão com os da outra, o que pode ser uma explicação para a oitava ser uma consonância perfeita. Quanto a quinta podemos constatar que todos os harmônicos ímpares da têm frequências situadas entre os harmônicos da tônica; apenas os harmônicos pares coincidem. Em particular, o terceiro harmônico da quinta, com frequência 9/2f1 encontra-se "perigosamente próximo" às frequências do quarto e quinto harmônicos da tônica podem se superpor, e portanto surgirão batimentos, mesmo que o intervalo de frequências fundamentais esteja perfeitamente afinado. Dando continuidade a análise da tabela, podemos verificar que para outros intervalos como quartas, terças e sextas, a proporção de harmônicos que coincidem aumenta rapidamente e vai descendo na ordem dos harmônicos. Esta pode ser uma possível explicação para a causa da consonância e dissonância.

\subsection{O tratado de Jean Philipe Rameau}

No princípio do século XVIII, o compositor e teórico musical Jean-Philippe Rameau (1683-1764) sistematizou em seu Traité de Harmonie (1722) grande parte da 
teoria harmônica de seu tempo. O primeiro capítulo dessa obra trata dos fundamentos matemáticos presentes na música. Os capítulos seguintes tratam de natureza e propriedades de acordes e tudo aquilo que é necessário para fazer música perfeita, princípios de composição e de acompanhamento.

Na perspectiva da composição de intervalos Rameau sistematiza a partir da oitava, quarta e quinta todos os intervalos da escala diatônica, já que compondo razões com tais intervalos fundamentais, o mesmo pode produzir qualquer outra nota presente em tal escala. Por exemplo, a segunda pode ser escrita como uma quinta mais uma quinta menos uma oitava: $2^{\mathrm{a}}=5^{\mathrm{a}}+5^{\mathrm{a}}-8^{\mathrm{a}}$, ou seja $[(2 / 3) \mathrm{x}(2 / 3)] / 1 / 2=8 / 9$, que é justamente a relação de um tom, desta forma subindo um tom a partir da segunda temos uma terça maior, ou $3^{\mathrm{a}}=2^{\mathrm{a}}+2^{\mathrm{a}} \operatorname{logo}$ a $3^{\mathrm{a}}=[8 / 9]^{2}=64 / 81$, a sexta é uma quinta mais um tom, $6^{\mathrm{a}}=5^{\mathrm{a}}+2^{\mathrm{a}}=[(2 / 3) \times(8 / 9)]=16 / 27$ e a sétima é uma sexta mais um tom, ou $7^{\mathrm{a}}=6^{\mathrm{a}}+2^{\mathrm{a}}=(16 / 27) \times(8 / 9)=128 / 243$.

Após o desenvolvimento da relação entre razões, proporções e a formação de intervalos musicais Rameau passou a fazer uma análise de cada um dos intervalos, tal tratamento seguiu com a oitava, quinta, quarta, segunda, terça, sexta e sétima. No entanto, apesar de separar em ordem crescente os intervalos mais e menos consonantes, talvez um dos pontos mais brilhantes de seu trabalho tenha sido sua análise sobre a oitava, já que neste momento Rameau apresenta um argumento amparado numa idéia intuitiva de ressonância para tratar a oitava como uma replicação, desta forma harmonizar um intervalo x ou um intervalo 2.x passa a ser o mesmo problema, ou seja, cada vez que dobramos uma determinada frequência esta nova frequência representa a mesma intervalo musical. Tal constatação traz um novo tratamento para a teoria musical, pois a partir deste momento os acordes dó-mi-sol, mi-dó-sol e sol-dó-mi passam a ser tratados como inversões do mesmo acorde. 
Rameau estava ciente do movimento transformador da acústica musical no século XVII e isso se traduz em seu tratado que além de possuir um tratamento matemático do som como os tratados tradicionais, apresenta regras de procedimento musical inovadoras quando comparado com os tratados de sua época.

A síntese histórica apresentada, bem como a análise preliminar do Tratado de Harmonia de Rameau sustentam parte fundamental desta pesquisa, já que o aprofundamento das questões históricas, a compreensão da música teórica do ponto de vista físico-matemático, a extração de elementos que remontem a mudança paradigmática atrelada ao papel do experimento na ciência do Renascimento e a elaboração de recursos instrucionais que tornem tais conceitos acessíveis aos estudantes do ensino médio compõe os objetivos centrais deste trabalho.

\subsection{A música ocidental e o surgimento de um novo paradigma}

É válido ressaltar que os conceitos musicais apresentados variam de uma cultura para outra e neste sentido a música contemporânea emancipa o conceito de consonância, de tal forma que este conceito deixa de ser parte do paradigma estruturante do fazer musical. Além disso, a harmonia musical faz uso de outra concepção teórica, de tal forma que a análise apresentada tem um domínio de validade restrito à musica ocidental no período entre o Renascimento e o século XIX.

Vale ainda salientar que apesar do interesse específico na descrição física dos fenômenos imbricados com a música, não há nenhuma intenção de reduzir a música a um tratamento científico, pois uma forma de arte nunca será objetiva e precisa a ponto de ser uma unanimidade, mas as simetrias e belezas observadas nas leis que governam a combinação das estruturas matemáticas usadas na descrição dos sons em geral, e que 
permitem analisar o espectro sonoro de cada instrumento musical guardam estreita relação com a área científica. 


\section{CAPÍTULO 3 \\ A ACÚSTICA MUSICAL SOB UMA ÓTICA HISTÓRICO-EPISTEMOLÓGICA}

\subsection{A epistemologia de Thomas Kuhn}

Para fins de concretizar o estudo epistemológico mencionado foram realizadas as leituras de autores, tais como Thomas Kuhn, Gaston Bachelard e Karl Popper, visando verificar se conceitos tais como Revolução Científica, Paradigma, Crise Epistemológica enunciados por Thomas Kuhn --, obstáculo epistemológico (Gaston Bachelard) e falseamento (Karl Popper) são transferíveis ao quadro teórico a luz do qual foi analisada a história da acústica.

Em 1962 o físico, historiador e filósofo da ciência Thomas Kuhn publicou a obra “A estrutura das Revoluções Científicas", onde apresentava uma proposta de desenvolvimento do conhecimento científico.

$\mathrm{O}$ aspecto mais importante da sua teoria reside na ênfase dada ao caráter revolucionário do próprio progresso científico. Este se dá, segundo Kuhn, mediante rupturas e não num processo cumulativo. Neste sentido, o projeto epistemológico de Thomas Kuhn faz uso dos conceitos de "paradigma", "ciência normal", e "revolução científica". Segue abaixo a definição destes conceitos extraídas da obra de Kuhn:

- Paradigma: Conjunto de realizações científicas reconhecidas por uma comunidade por algum tempo, proporcionando os fundamentos para sua prática posterior.

- Ciência Normal: Pesquisa firmemente baseada em uma ou mais realizações científicas passadas (paradigma), ou seja, trabalho de acabamento sobre um paradigma estabelecido. 
- Revolução Científica: Episódios de desenvolvimento não cumulativo, nos quais um paradigma mais antigo é total ou parcialmente substituído por um novo incompatível com o anterior.

Segundo Kuhn, três tipos de fenômenos podem incidir em crise, desencadeando o desenvolvimento de novas teorias:

A) fenômenos já bem explicados pelos paradigmas existentes. Neste caso, raramente há motivos para a construção de novas teorias, mas, quando isso acontece, elas dificilmente são aceitas;

B) fenômenos cuja natureza é indicada pelo paradigma existente, mas cujos detalhes somente podem ser entendidos após uma maior articulação da teoria. São os mais pesquisados, e a pesquisa sobre esses visa antes a articulação do paradigma dominante do que à proposição de novas teorias;

C) fracassada a tentativa de articulação, surge o terceiro tipo: as anomalias, que tem por traço característico a recusa do paradigma vigente. Neste caso, geram-se novas teorias.

Os momentos de crise nos paradigmas têm três soluções terminativas possíveis, com alguma correspondência com os tipos de fenômenos antes indicados:

A) a ciência normal mostra-se capaz de tratar do problema que provocou a crise e não surge outro paradigma a disputar a hegemonia;

B) o problema persiste mesmo diante de novas e radicais abordagens, assim ao persistir insolucionado, o paradigma pode perdurar, na falta de outro que aponte solução;

C) emerge um candidato a paradigma que lutará para suplantar o vigente. Neste caso, esta transição para um novo paradigma é denominada revolução científica: 
"Consideramos Revoluções Científicas aqueles episódios de desenvolvimento nãocumulativo, nos quais um paradigma mais antigo é total ou parcialmente substituído por um novo, incompativel com o anterior." (KUHN).

Assim, segundo Kuhn a ciência se desenvolve parcialmente em períodos de ciência normal e parcialmente nas Revoluções científicas, conforme o ciclo representado de maneira simplificada na imagem abaixo:

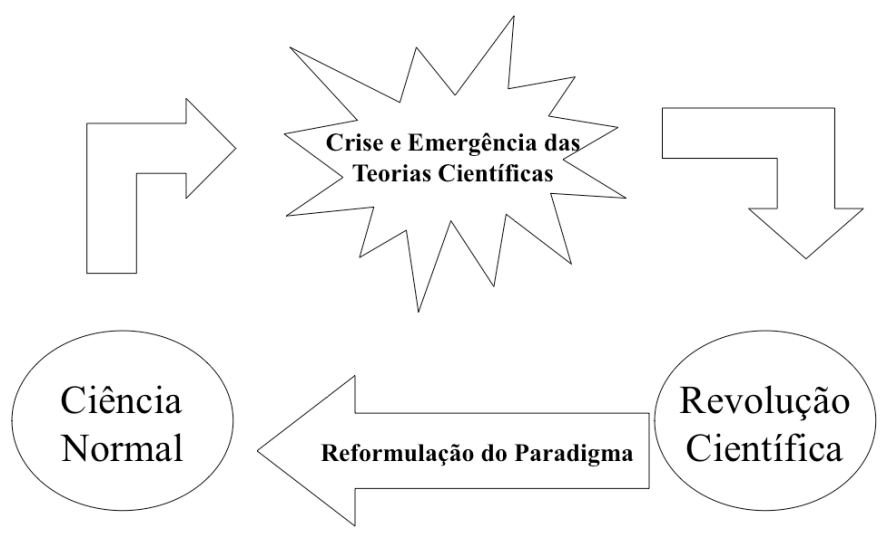

Visando relacionar a epistemologia de Kuhn com o ensino de física Zylbersztajn (1991) propõe uma estratégia de ensino em que alunos de disciplinas científicas sejam encarados como cientistas kuhnianos. Os passos instrucionais delineados, nesta estratégia, são:

1) Elevação do nível de consciência conceitual: os alunos, nesta etapa, devem conscientizar-se de suas concepções prévias.

2) Introdução de anomalias: o objetivo principal deste passo instrucional é criar uma sensação de desconforto e insatisfação com as concepções existentes, através do conflito entre estas e o pensamento científico. Demonstrações, experimentos, argumentos teóricos podem ser aplicados. É o equivalente instrucional ao período de ciência extraordinária, no modelo de Kuhn. 
3) Apresentação da nova teoria: nesta etapa, os alunos recebem um novo conjunto de idéias que irão acomodar as anomalias. O professor faz, então, o papel de um cientista tentando converter outros a um novo paradigma.

4) Articulação conceitual: trata-se do equivalente instrucional aos quebra-cabeças da ciência normal. Neste estágio, esforços são dirigidos para a interpretação de situações (experimentais ou teóricas) e à resolução de problemas.

\subsection{As escolhas epistemológicas para a releitura da Acústica Musical}

Um dos principais objetivos desta pesquisa é o desenvolvimento de uma releitura histórica a partir de uma análise epistemológica, para isso faz-se necessário a escolha de um referencial epistemológico. Neste sentido foram estudados alguns autores, dentre eles Thomas Kuhn, Karl Popper e Gaston Bachelard. Entretanto para o desenvolvimento da análise à ser feita neste texto o autor utilizado como referencial teórico será Thomas Kuhn, já que um dos objetivos deste trabalho é mostrar que na Acústica, assim como na Astronomia e na Mecânica, os séculos XVI e XVII foram marcados por uma importante mudança no procedimento científico, sobretudo no que diz respeito ao papel da experimentação. Neste sentido, buscar evidências ao longo da história da Acústica que evidenciem que neste período o conhecimento científico sobre a música passou pode ser tratado como uma Revolução Científica foi uma importante etapa deste trabalho.

A escolha pela epistemologia de Thomas Kuhn baseia-se essencialmente na crença de que a ciência é uma construção sócio-histórica, e que seu desenvolvimento histórico não é cumulativo, desta forma os procedimentos e crenças da comunidade científica estão amplamente vinculadas a aspectos culturais, políticos, econômicos e históricos da 
sociedade. Sendo assim, os trabalhos de Gaston Bachelard e de Karl Popper serão mencionados e utilizados pontualmente na sala 8 da exposição e eventualmente serão utilizados os conceitos de falseamento e de obstáculo epistemológico. Entretanto ao longo do trabalho o tratamento da ciência como uma construção sócio-histórica será sempre privilegiado em detrimento de uma visão que estabelece um critério de demarcação lógico.

\subsection{O nascimento da Acústica como uma ciência experimental}

Pode-se considerar um dos primeiros registros da história da Acústica o experimento do Monocórdio realizado pelos pitagóricos. Tal experimento consistiu em esticar uma corda e com um cavalete alterar seu comprimento, permitindo relacionar intervalos musicais com razões da corda determinadas pela posição do cavalete. Assim pôde-se associar razões do comprimento da corda a intervalos musicais. Vale ressaltar que a tradição pitagórica era fortemente vinculada a um dogmatismo aritmético, e neste sentido o resultado obtido foi generalizado a outros contextos, de tal forma que acreditava-se que, assim como na corda, qualquer entidade física na proporção 1:2 gerava uma oitava por exemplo.

Como consequência do experimento do monocórdio estabeleceu-se a composição de razões como uma maneira de conceber a escala pitagórica. Assim pôde-se a partir disto concluir o que atualmente os músicos intitulam de escala diatônica ( dó, ré, mi, fá, sol, lá, si e dó).

A tradição musical pitagórica foi transmitida para a Idade Média principalmente através do tratado De Institutione musica, escrito no início do século VI d.C. por Boécio (475-524). Tal obra influenciou a grande maioria de tratados teórico-musicais da Idade Média determinando a predominância do pitagorismo na música teórica medieval e como 
conseqüência uma abordagem matemático-especulativa como base teórica para resolução dos problemas teórico-musicais.

No final do século XVI, Vincenzo Galilei apresentou uma crítica ao dogmatismo aritmético de Pitágoras. Fazendo uso de diversos experimentos, entre eles o próprio monocórdio, Vincenzo Galilei mostrou que diversas razões podem estar associadas ao mesmo intervalo musical. Assim, sua crítica aos modelos teóricos de Pitágoras explicitava a concepção de que o caminho para construir uma ciência musical deveria contemplar uma perspectiva experimental, mudando a maneira de pensar tal ciência.

Tal crítica evidenciava a importância de uma perspectiva experimental para a análise do comportamento do som. Assim, o Renascimento pode ser marcado como o momento em que o estudo da acústica deixou de se basear em um dogmatismo aritmético para intensificar sua perspectiva empírica e a partir de então se constituir como uma ciência essencialmente experimental.

Da perspectiva musical, o Renascimento caracteriza-se pela evolução da polifonia melodias tocadas simultaneamente - e conseqüentemente o desenvolvimento da harmonia. Realizando especulações matemáticas concernentes a esta área em seu Musica Teórica, Ludovico Fogliani forneceu fortes subsídios para que Gioseffe Zarlino organizasse em sua obra Inztituzioni Armonique (1558) a base da educação científico-cultural da época.

Dando continuidade ao quadro teórico mencionado, o espanhol Francisco Salinas (1513-1590), bem como o padre e matemático francês Marin Mersenne (1588-1648) que, dedicando-se ainda à acústica, apresenta-se como o primeiro teórico a fundamentar o estudo de harmonia no fenômeno da ressonância. Mantendo correspondências assíduas com René Descartes (1596-1650), Mersenne discutiu problemas e aspectos pouco claros do Compedium Musicae escrito pelo filósofo francês em 1618. Descartes estabeleceu no 
compêndio referidos conceitos estéticos de influência marcante ao Tratado de harmonia, escrito por Jean Philippe Rameau (1683-1764) cem anos mais tarde. Modificando substancialmente a concepção pitagórica, Galileu Galilei escreveu em 1638 que nem o comprimento, nem a tensão e nem a densidade linear de cordas apresentava-se como razão direta e imediata subjacente a intervalos musicais, mas razões dos números de vibrações e impactos de ondas sonoras que atingiam o tímpano. Considerando o som que alcançava o ouvido invés do objeto vibrante que o produzia, Galileu verificou que a altura musical relacionava-se diretamente à freqüência registrando rastros de arranhões desenhado numa placa metálica provenientes de uma haste vibrante solidária a uma membrana que recebia vibrações sonoras.

\subsection{A natureza da ciência e o ensino de Acústica}

Tão importante quanto discutir conceitos da física é discutir como estes conceitos se constroem. Esta é uma das concepções que permeiam este trabalho, ou seja, discutir a natureza da ciência pode conduzir o estudante de física a se relacionar de maneira mais crítica e atuante com relação à questões que envolvem o desenvolvimento científico e tecnológico.

Neste sentido, o curso de gravitação universal tem se apresentado em diversos cursos e nos livros didáticos como o único momento em que a maneira de se construir ciência sofreu grandes modificações, ou seja, localiza-se pontualmente a Revolução Científica ocorrida no Renascimento no estudo da Gravitação. Entretanto a valorização do caráter empírico da ciência ocorreu neste momento histórico em diversos contextos conceituais e um dos objetivos deste trabalho é mostrar, a partir de uma releitura histórica da acústica, que também neste contexto conceitual o paradigma científico mudou. Assim a 
abordagem histórica da acústica pode se configurar como uma estratégia consistente de um ensino de física que busca evidenciar que o fazer científico é mutável em função do tempo, do momento histórico e da conjuntura social, política e econômica.

Para isso, este texto buscará apresentar um material que evidencia um recorte da história da física, as concepções epistemológicas de Thomas Kuhn e possibilidades de diversificação das estratégias de ensino decorrentes desta percepção.

\subsection{A epistemologia de Kuhn, o ensino de Acústica e a natureza da ciência}

Entre as virtudes do projeto epistemológico de Thomas Kuhn destaca-se o fato dele evidenciar que o paradigma científico é mutável, assim as crenças, métodos e instrumentos para se fazer ciência variam de acordo com o cenário sócio-histórico do mundo. Neste sentido, Kuhn explicita a idéia de que não há e não pode haver um critério de demarcação puramente lógico para delimitar o que é ciência. Desta forma, uma importante análise a se fazer ao estudar história da ciência está relacionada com as mudanças de paradigma decorrentes de momentos especiais na história da humanidade.

Neste sentido, o Renascimento pode ser um destes momentos. E os dados e bibliografias analisados sugerem que neste momento da história a experimentação passou a ser muito valorizada e particularmente na Acústica Musical substituiu uma maneira dogmático-aritmética de interpretar o mundo científico.

Desta forma, o ensino da Acústica pode levar os estudantes a compreender que a maneira de fazer ciência varia e que particularmente neste período ( Renascimento) o paradigma científico passou por uma grande transformação. É importante ressaltar que as discussões epistemológicas, embora não explicitadas no ensino médio, permeiam o 
desenvolvimento do curso, o discurso do professor e sem dúvida a concepção de ciência dos estudantes.

É muito comum que se discuta esta ruptura no ensino da Gravitação Universal, entretanto explorar esta discussão em outros âmbitos conceituais pode ser muito importante para a discussão sobre como a ciência se constrói. A análise histórica desenvolvida no presente trabalho tem como um de seus objetivos evidenciar que esta é uma leitura possível para o desenvolvimento histórico da relação físico-musical.

\subsection{O Renascimento: Uma Revolução Científica generalizada?}

Segundo Gil da Costa Marques e Maria José Bechara:

"Na transição entre a mentalidade medieval européia, marcadamente contemplativa e submissa às inquestionáveis verdades da fé, e a mentalidade moderna, com a volta da racionalidade para o entendimento do mundo, surge um movimento artístico e científico denominado Renascimento (séculos XV e XVI). Esse movimento criou a base conceitual e introduziu valores que permitiram a revalorização da razão e o advento da ciência moderna no século XVII.

Como forma de se opor à visão de mundo dominante no período medieval, isto é, o teocentrismo (Deus como centro), os renascentistas revitalizam o pensamento grecoromano (dai o nome de Renascimento), inicialmente fazendo do homem o centro do conhecimento, ou seja, trazendo à tona o antropocentrismo. O Renascimento proporciona o desenvolvimento do racionalismo, isto é, a explicação do mundo por verdades estabelecidas pela razão, e não pela fé, e permite que seja desenvolvido o espírito de observação experimental com a mente mais aberta ao livre exame do universo para descobrir as leis que regem os fenômenos naturais. 
Para conhecer a realidade, surge, durante o Renascimento, um novo método de investigação, o empirismo, baseado na observação e experimentação sistemática, que é uma das bases das ciências naturais modernas. Conhecer algo a respeito da natureza não se limita ao exercício da reflexão; ela se faz a partir da realidade observada. Este conjunto de atitudes contrapunha-se à mentalidade contemplativa e submissa às verdades da fé dominante na Idade Média, abrindo caminho para o surgimento da ciência moderna no século XVII."

A discussão apresentada nos parágrafos anteriores pode suscitar a seguinte pergunta: será o Renascimento um momento histórico que a ciência ganhou um caráter experimental em todos os seus contextos conceituais? Naturalmente a resposta a esta questão necessita de pesquisa em outros âmbitos conceituais, entretanto parece haver indícios de que neste período a maneira de se entender a física mudou.

Assim esta pesquisa buscou apresentar elementos da história da acústica que permita afirmar que neste contexto conceitual isto é verdade. Porém esta análise parece ser passível de ser generalizada para as ciências de maneira geral.

\subsection{Uma discussão sobre o currículo de física do Ensino Médio}

Tem se intensificado as discussões sobre reformas curriculares no ensino de física no Brasil. A implementação de projetos de reformulação curricular tais como Escola Plural em Minas Gerais, do São Paulo faz Escola, nova proposta curricular no Acre, no Rio Grande do Sul, entre outros tem evidenciado a preocupação do Estado e dos pesquisadores da área de ensino de física com relação ao currículo tradicionalmente estabelecido no país. Neste sentido, pretende-se neste trabalho discutir a importância da inserção que Acústica tem ou deveria ter no curso de física. 
Para além de permitir uma compreensão mais ampla dos fenômenos sonoros, o ensino da acústica pode promover a construção de uma percepção, por parte dos estudantes, acerca de como o conhecimento científico é construído. Tal percepção deve envolver a noção de que as crenças que embasam o conhecimento científico mudam ao longo da história, assim, a abordagem histórica deve propiciar uma reflexão sobre como a maneira de entender os fenômenos sonoros mudaram com o passar do tempo. 


\section{CAPÍTULO 4 \\ A ELABORAÇÃO DA EXPOSIÇÃO DIDÁTICA}

Este capítulo objetiva mostrar o projeto de elaboração de uma exposição didática aprovado pelo Cnpq (Edital MCT/CNPq n. ${ }^{\circ}$ 12/2006) e pela direção da Estação Ciência. Esta exposição deverá ser realizada no início de 2011 e será composta por oito salas temáticas que se relacionam, e de alguma maneira procuram divulgar os conceitos enunciados no capítulo 2 deste trabalho. Desta forma segue abaixo uma explicação dos principais objetivos e atividades de cada sala.

Dentre os principais objetivos do projeto estão:

- Divulgação científica da relação entre a física, a matemática e a música sob uma perspectiva histórico-epistemológico-didática, contribuindo para a ampliação do conhecimento científico-tecnológico da população em geral.

- Considerando a necessidade de valorizar a ciência no âmbito das relações entre física e música, tornar acessível ao leigo o significado de conceitos de natureza acústico-musical tais como som, timbre, escala, intervalo musical, consonância e dissonância, ressonância, afinação, harmonia, harmônicos, etc.

- Fortalecer o acervo da Estação Ciência por meio da aquisição de dispositivos para a exposição que permanecerão nessa instituição após seu término.

- Por meio da reprodução direta ou analógica de experimentos envolvendo conceitos matemáticos, físicos e musicais, propiciar ao visitante, em uma linguagem de divulgação científica, a experiência vivida por cientistas no passado, fazendo uso de recursos tecnológicos modernos. 
- Propiciar um espaço a profissionais envolvidos em ensino/aprendizagem para vivenciar atividades de cultura e extensão às suas atividades curriculares, fornecendo-os sugestões para aplicações em suas atividades de ensino e contribuindo para melhoria do ensino, em particular, de matemática, física e música, valorizando a criatividade, experimentação e interdisciplinaridade.

- Através de experimentos interativos, despertar o interesse e a curiosidade do visitante pelo estudo e eventual aprofundamento de conceitos de natureza matemático-acústico-musicais abordados na exposição, estimulando jovens de todas as camadas sociais, para as áreas científico-tecnológicas.

- Fortalecer a bibliografia e historiografia da divulgação científica da relação matemáticamúsica, através da elaboração de um catálogo contendo os temas da exposição apresentados segundo uma perspectiva histórico-espitemológico-didática.

- Aumentar a apreciação da importância da ciência e tecnologia, explorando particularmente relações matemáticas em conceitos musicais por meio do uso de experiências didáticas que remontam ao histórico do desenvolvimento de tais conceitos.

- Apresentar uma leitura histórico-epistemológica das relações entre matemática e música durante a Revolução científica caracterizando aspectos que levaram à mudança de concepção da música de uma visão matemático-especulativa para uma perspectiva físicoempírica.

Conforme previamente mencionado sob uma ótica estrutural a exposição propõe 8 módulos dispostos em salas capazes de transmitir as idéias centrais da relação entre física, matemática e música, sendo estas:

-- 1) Motivações e questões relevantes para a compreensão da Série Harmônica 
-- 2) $\mathrm{O}$ experimento do Monocórdio: razões $\mathrm{x}$ intervalos musicais e a sistematização matemática da escala

-- 3) Renascimento: o nascimento da música como ciência experimental

-- 4) Escalas e Temperamento

-- 5) Série Harmônica/Série de Fourier

-- 6) Consonância e Dissonância: do simbolismo aritmético a uma concepção física

-- 7) O som dos planetas

-- 8) Da matemática-especulativa à matemática-empírica: uma revolução científica na música

Abordando temas situados precisamente na interface física/matemática/música configurada convenientemente, cada um dos referidos módulos deve possuir textos ou hipertextos curtos concernentes à história da construção e evolução dos conceitos acústico/musicais diretamente associados ao tema daquele módulo, bem como dispositivos interativos -- eletrônicos, mecânicos etc -- de animação audiovisuais. Fazendo uso de múltiplas representações --, tais dispositivos destinam-se ao aprimoramento da assimilação, por parte dos visitantes, dos conceitos matemático/musicais subjacentes ao tema central do módulo em questão. A exposição pode eventualmente incluir vídeos ilustrando um diálogo hipotético entre teóricos da ciência abordando temas pertinentes. Os módulos interconectam-se através das referências dos textos, hipertextos e dispositivos, refletindo a evolução histórico-epistemológica das explicações para conceitos matemático-musicais. Cabe aqui ressaltar que a ordem com que se apresentam os módulos não se refletirá necessariamente na organização espacial da exposição.

Com o intuito de reforçar as atividades de divulgação científica almejadas neste projeto, a dinâmica da exposição contempla ainda palestras com especialistas convidados, 
que viabilizem, na busca desse objetivo, maior diversidade de possibilidades para atingir a população em geral. Além disso, a exposição inclui um catálogo destinado ao visitante como auxílio na interação com as diversas atividades.

Vale ressaltar que neste capítulo a proposta é relatar o projeto inicial da exposição e que apenas mais adiante pretende-se discutir sua execução, os problemas encontrados e os resultados obtidos.

\subsection{Sala 1: Motivações e questões relevantes para a compreensão da Série Harmônica}

Tendo em vista que os conceitos acústico-musicais, tais como o de Série Harmônica, não são em geral muito intuitivos, este módulo terá por objetivo principal trazer a motivação necessária para as descobertas subseqüentes mostradas nos módulos posteriores motivando a compreensão dos conceitos envolvidos na exposição. Para isto serão apresentados painéis e experiências que levam o participante a buscar explicações científicas para conceitos acústico-musicais. Nesse sentido, são estabelecidas uma série de perguntas, que guiam o participante da exposição à compreensão, nos módulos posteriores, dos conceitos mencionados.

Exemplos de perguntas relevantes:

Qual é a diferença física que permite reconhecer as vozes das pessoas, ou o timbre de diferentes instrumentos musicais?

O que é som?

Quantas vozes diferentes você é capaz de reconhecer? Por que isso acontece?

O que é timbre?

Como se forma a escala musical?

Por que existem sons que consoam e outros que dissoam? Concordam ou discordam? 
Por que um móvel próximo a um aparelho de som ligado pode vibrar?

Porque quando se sopra muito forte uma flauta escuta-se ao invés da nota desejada uma nota bem mais aguda?

Qual a relação entre calendários e escalas musicais? Por que não utilizamos o mês lunar (29,5 dias) em nosso calendário?

Como se afinam os instrumentos?

Porque ao ouvir os badalos de um sino pode-se escutar um som agudo?

Você conhece as diferenças e semelhanças entre notas e acordes?

Além das perguntas que serão apresentadas em painéis este módulo contará com uma série de de painéis, softwares e experimentos que devem motivar o visitante a elaborar questões sobre o assunto. Entre eles estarão um painel histórico que trate de conceitos básicos da acústica e da música, um painel acompanhado do célebre experimento de Newton sobre a decomposição da luz branca em um prisma trazendo assim uma analogia entre o som e a luz,ou seja, mostrando que assim como a luz branca pode ser decomposta em outras ondas um som complexo pode ser decomposto em seus respectivos harmônicos; um painel com as perguntas apresentadas acompanhado de um conjunto de instrumentos que o visitante poderá tocar e portanto ouvir seus timbres e um software no qual o visitante reconhecerá a fim de diferenciar diversos timbres.

\subsection{Sala 2: $O$ experimento do Monocórdio: razões $\mathrm{x}$ intervalos musicais $\mathrm{e}$ a sistematização matemática da escala}

Apresentando um histórico do experimento do monocórdio de Pitágoras, esta sala permite sua reprodução bem como a exploração e experimentação de suas principais conseqüências -- às consonâncias perfeitas $8^{\mathrm{a}}, 5^{\mathrm{a}}$ e $4^{\mathrm{a}}$ subjazem as razões simples 1:2, 2:3 e 
3:4 -- culminando com a construção da escala diatônica pelos pitagóricos. Sob uma ótica mais ampla, um importante legado do experimento de Pitágoras consiste na percepção de que subir ou descer um intervalo musical corresponde, anacronicamente falando, a multiplicar ou dividir o comprimento de corda que produz a nota mais grave ou mais aguda pelo fator correspondente ao intervalo referido, respectivamente. Este resultado poderá ser experimentado por dispositivos computacionais que contenham a simulação do monocórdio, produzindo intervalos musicais a partir de razões estabelecidas.

Tal dispositivo fornece ainda diferentes problemas matemático/musicais envolvendo composição/decomposição de razões de intervalos musicais, tais como: a) Seja um comprimento L correspondente a uma nota dada. Como podemos obter sua oitava superpondo somente intervalos de $4^{\mathrm{a}}$ e $5^{\mathrm{a}}$ e sua quinta superpondo somente intervalos de $4^{\mathrm{a}}$ e $8^{\mathrm{a}}$ ? b) Partindo da nota $d o$, como podemos atingir o ré, superpondo somente consonâncias pitagóricas? Ou partindo da nota $m i$, como podemos atingir um sol, superpondo somente consonâncias pitagóricas? c) Seja ré a nota emitida pela corda do monocórdio de comprimento L. Que movimento intervalar estaremos realizando ao multiplicarmos L por 2:3, 2:3, 2:3, e 2? Verifique a nota no monocórdio, conferindo seu som no piano. d) Seja L o comprimento correspondente a uma nota dada. Que intervalos são obtidos entre a nota dada e aquelas produzidas por: 4L:9, 9L:16, 8L:9. e) Seja L o comprimento correspondente a uma nota dada. Qual o comprimento necessário para produzir a nota obtida ao subir uma oitava e uma quinta e, em seguida, descer duas quartas? Ouça a nota resultante no monocórdio, comparando-a com aquela atingida ao realizarmos tal procedimento no piano.

As diferentes situações problemáticas podem conduzir o usuário a descobrir, a partir do conhecimento dos resultados do experimento do monocórdio, as escalas 
pentatônica, diatônica e cromática com suas respectivas razões conformadoras subjacentes. Tais situações conduzem ainda à problemática do não ajuste entre o ciclos de quintas e o de oitavas, associada à impossibilidade de resolução de uma equação matemática para valores inteiros de suas incógnitas. Esta impossibilidade resulta na coma pitagórica, que representa a „semente da imperfeição“, de natureza semelhante à irracionalidade na matemática e impossibilidade de ajuste preciso entre ciclos naturais da Lua e da Terra em torno do Sol na astronomia (Abdounur, 1999, pp.12). Tais observações estabelecem um ,,link“ com a sala Escalas e Temperamento, uma vez que a coma pitagórica e as outras geradas a partir das tentativas de construção de escalas musicais baseadas em números racionais representam o motor para o desenvolvimento dos diversos temperamentos.

Nesta sala haverá um painel acompanhado de um experimento que visam explicar o que é intervalo musical, vale ressaltar que este conceito é fundamental para que o visitante amplie sua compreensão da exposição, desta forma esta sala trará os intervalos musicais de múltiplas formas ( o visitante escutará os intervalos, lerá como estes são concebidos e utilizará um experimento geométrico construído para facilitar a compreensão do conceito). Além disso, nesta sala haverá um segundo painel histórico salientando o que foi e qual é a importância do experimento do monocórdio acompanhado do próprio experimento (monocórdio) e de um terceiro painel sobre a construção da escala pitagórica relacionando a composição de razões matemáticas com a formação da escala. Este processo poderá ser reproduzido na sala fazendo uso de um tricórdio e de um treze-córdio construídos para a formação e vivência da escala cromática. Finalmente, haverá um último painel com perguntas sobre a formação de escalas e um software que mostre como se dá o processo de construção da escala. 
Além disso, a sala terá a reprodução da imagem de Franchinno Gaffurius já apresentada acompanhada da própria imagem e haverá uma animação com um diálogo entre Pitágoras e Aristoxenus visando explicitar as concepções pitagóricas sobre a música.

\subsection{Sala 3: Renascimento: o nascimento da música como ciência experimental}

Baseando-se nas leis das cordas vibrantes, Mersenne (1588-1648), no seu livro "L‘Harmonie Universelle" (Buccolini, 2003) estabelece os princípios fundamentais da harmonia.

O matemático francês apresenta assim, a gama temperada e descreve as leis físicas que determinam as frequências das vibrações das cordas. Mersenne era ao mesmo tempo um filósofo e um cientista, considerando que as questões da harmonia não são apenas técnicas, de matemática ou de física, mas estão diretamente ligadas a questões filosóficas. Ele enunciou as seguintes leis relativas às cordas vibrantes:

$1^{\text {a }}$ Para uma determinada corda com determinada tensão, o período de vibração da corda varia consoante o seu comprimento. Como a freqüência é o inverso do período, significa então que a freqüência varia com o inverso do comprimento.

$2^{\mathrm{a}}$ Dado o comprimento de uma corda, o período varia como o inverso da raiz quadrada da tensão. Em particular, quanto mais se estica a corda, mais os sons se tornam agudos.

$3^{\mathrm{a}}$ Dados o comprimento e a tensão de uma corda, o período varia como a raiz quadrada da densidade linear do seu material; o que explica produzirem as cordas mais grossas do violino sons mais graves que as mais finas.

Os conceitos expostos acima juntamente com a experiência de Wallis (Lindsay, 1972) -- que consiste em esticar uma corda e colocá-la para vibrar, mostrando assim seus

diferentes modos de vibração - dão subsídios para a compreensão do conceito de 
harmônico, já que a freqüência emitida pela corda depende do número de nós. Por outro lado, observam-se experimentalmente os diversos modos simultâneos de vibração de uma corda, relacionados às várias freqüências, por sua vez associadas aos harmônicos.

Além de fornecer subsídios à verificação da Fórmula de Mersenne, este módulo pretende elucidar o conceito de ressonância bem como reproduzir a experiência de Wallis que retrata os modos de vibração de uma corda vibrante, mostrando assim que ao gerar um som, têm-se simultaneamente vários modos de vibração. Em particular ao gerar uma nota, junto com esta tem-se cada múltiplo de sua freqüência fundamental, denominado harmônico, de acordo com a figura abaixo.

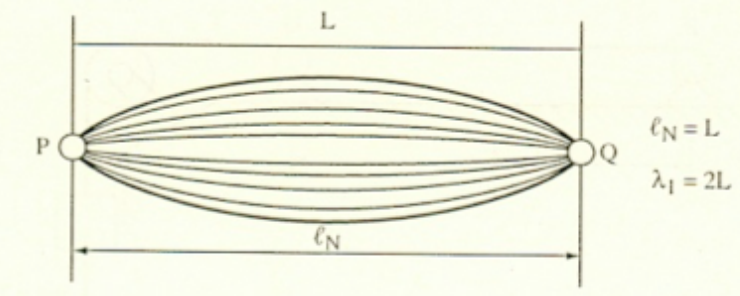

$\leftarrow$ Nota fundamental

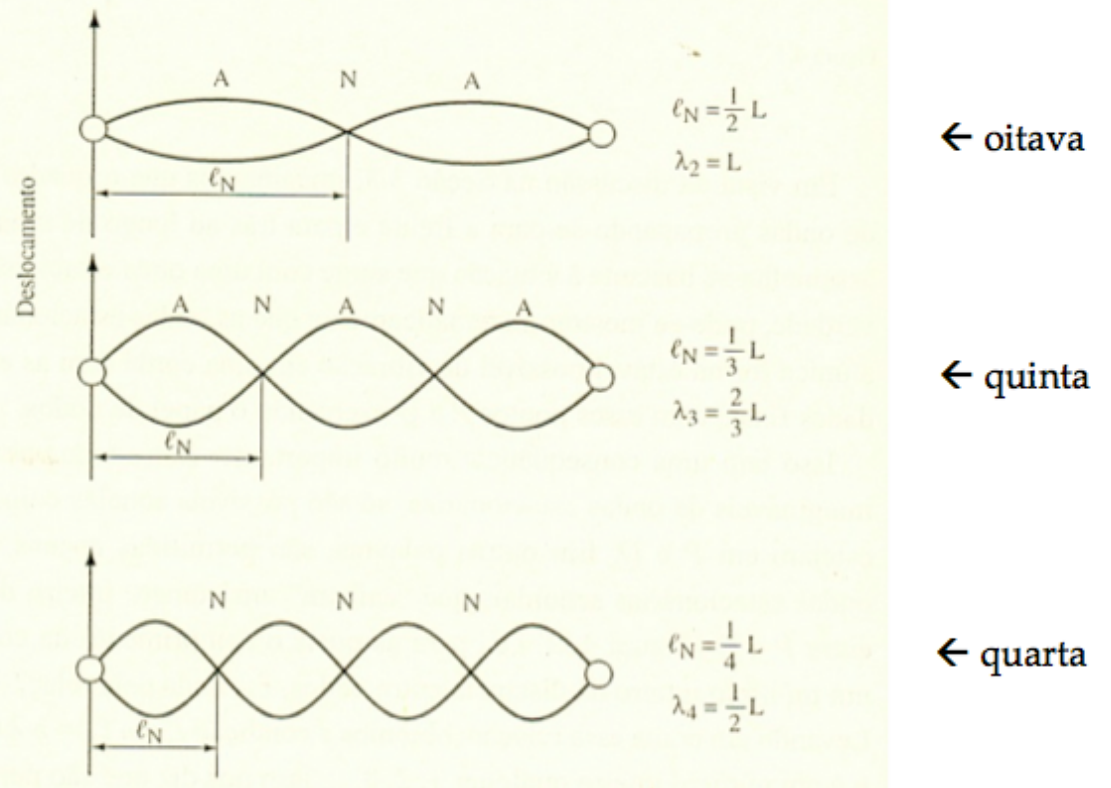

Figura 10: Imagem retirada do livro "A física e a psicofísica da música” de J. G.

Roederer apresentando os modos de vibração de uma corda 
Para isto esta sala apresentaria o experimento de cordas vibrantes de Wallis acompanhado de um painel explicativo, um experimento e um painel explicativo evidenciando a Fórmula de Mersenne-Galileo e dois painéis que tratam do histórico do século XVII e da valorização do experimento no procedimento científico e do fenômeno da Ressonância acompanhado de um experimento com um conjunto de diapasões com caixas de ressonância que entram ou não em simpatia. Além disso, a sala terá uma animação com um diálogo entre Vincenzo Galileo e Joseph Zarlino sobre o papel do simbolismo matemático e da experimentação no fazer científico.

\subsection{Sala 4: Escalas e Temperamento}

Com paralelo significativo em astronomia, exibe-se uma grande crise da matemática/música nesta sala, que possui relevante poder heurístico no desenvolvimento das trajetórias não somente da matemática e da música como da interface em questão, por exemplo com o Temperamento. Para fins de explicitar o paralelo mencionado, configura-se a sala em três partes dispostas geometricamente em paralelo, exibindo as situações que intimaram a crise referida em matemática, em música e em astronomia, tais como respectivamente a impossibilidade de comensurar o lado e a diagonal do pentágono, a impossibilidade de encaixar um número inteiro de ciclos de quintas em um número inteiro de ciclos de oitavas e a impossibilidade de adequar um número inteiro de meses lunares a um número inteiro de anos solares.

O visitante será convidado a refletir sobre a formação da escala diatônica e terá a oportunidade de verificar a „harmonia,, entre aspectos matemáticos, musicais e físicos que convergem para constituir esse conjunto de notas musicais.

Esta sala tem o intuito ainda de apresentar as configurações de razões 
subjacentes às diversas afinações para a escala diatônica presentes na trajetória da matemática/música. Originando-se com escala pitagórica e conseqüentemente com a coma pitagórica - o que permite um , link“ com a sala $O$ experimento do Monocórdio:razões x intervalos musicais e a sistematização matemática da escala -, a idéia de temperamento perpassa por Arquitas de Tarento no século IV A. C. (Fallas, 1992), por Gioseffo Zarlino no século XVI (Zarlino, 1562,1571,1588), Descartes (Buzon, 1987) e Mersenne (Buccolini, 2003) no século XVII culminando, no século XVII e XVIII, com o temperamento igual. Estabelecendo aqui um „link“ com a sala Renascimento: o nascimento da música como ciência experimental, a dinâmica que conduz à construção de tal idéia possui estreita relação com conceito de logaritmo, desenvolvido a partir do início do século XVII e também abordado nesse módulo.

Com o intuito de dar vida ao percurso mencionado, bem como estabelecer referência com a qual comparar cada uma das referidas afinações; a sala permite ao usuário escutar "serialmente" as relações entre as notas para cada afinação acompanhadas das respectivas razões subjacentes, bem como comparar tais notas com aquelas produzidas pelas razões da Série de Fourier. Para fins de facilitar a percepção das pequenas diferenças existentes entre as afinações referidas, o dispositivo existente nesta sala permite ainda uma audição „em paralelo“ - por exemplo, ouvir a nota do para todas as afinações, a nota ré para todas as afinações, a nota $m i$ para todas as afinações etc -, o que aclararia, por exemplo, a percepção da „quinta do lobo“ - uma quinta natural diminuída da coma pitagórica.

Nesta sala haverá um painel histórico apresentando a necessidade de temperamento e um experimento sobre a coma pitagórica, um painel sobre a analogia entre o Temperamento e construção de calendários e mais dois painéis sobre a história do 
Temperamento e sua relação com os logaritmos acompanhado de um software que apresenta diversos tipos de temperamentos.

\subsection{Sala 5: Série Harmônica/Série de Fourier}

Munido de dispositivos mecânico-eletrônicos e eletrônicos tais como osciloscópio, analisador de espectro, cordas vibrantes conectadas a freqüencímetros etc, bem como instrumentos ou sintetizadores musicais; o objetivo principal do presente módulo consiste em explicitar a relação íntima entre a Série Harmônica de uma nota musical e a Série de Fourier da função representativa da referida nota, conceitos esses a princípio pertinentes exclusivamente aos respectivos domínios da Música e da Matemática.

Fazendo uso do osciloscópio, esse módulo propicia a reprodução "atualizada“ do experimento de Galileo (Cohen, 1984), que associa um som musical a uma forma de onda periódica. Com o intuito de ilustrar o significado da descoberta do pensador italiano, o presente módulo estende este experimento promovendo uma multirepresentação de um mesmo som por meio de diferentes dispositivos: um osciloscópio que traduz no tempo a forma de onda; um analisador de espectro que possibilita representações em freqüência do som, cujos termos parciais associam-se diretamente a seus harmônicos, estabelecendo um "link" com a sala "Renascimento: o nascimento da música como ciência experimental" no que concerne às cordas vibrantes em duas metades, três terços, quatro quartos etc, que reproduzindo o experimento de Wallis, fornecem configurações associadas respectivamente aos termos parciais da Série Harmônica do som produzido pela vibração da corda inteira; representações no tempo dos diferentes harmônicos senoidais do som referido etc.

Diante de todos os equipamentos mencionados, a emissão de um som, seja pela voz 
do usuário, por algum dispositivo sintetizador - ou ainda através de exemplos previamente gravados por instrumentos acústico-musicais -- produz simultaneamente uma onda no tempo, que se abre, como um arco-íris, em diferentes ondas senoidais - termos da Série de Fourier/Série Harmônica -- cuja composição -- pelo Princípio de Superposição de Saveur referido em textos locais -- resulta na onda mencionada; uma configuração de freqüências cujas amplitudes representam os coeficientes da Série de Fourier -- intensidades dos harmônicos do som inicial -- da onda referida, observadas ainda na sala "Renascimento: o nascimento da música como ciência experimental" particularmente no Experimento de Wallis, em que amplitudes das cordas vibram respectivamente de modo inteiro, em duas metades, em três terços etc.

Diante do dispositivo eletro-mecânico anterior, o usuário pode variar parâmetros do som emitido tais como altura, intensidade e timbre, observando a repercussão em cada representação supramencionada, tais como respectivamente na freqüência, na amplitude e na configuração do sinal elétrico expresso pelo osciloscópio; na freqüência fundamental, na amplitude dos harmônicos e na configuração dos harmônicos da representação fornecida pelo analisador de espectro etc.

Cabe nesse módulo explicitar a conexão que a fórmula de Galileo e Mersenne -relação entre freqüência emitida por uma corda tensa e comprimento, tensão e densidade linear do seu material -- estabelece entre Séries de Fourier/Série Harmônica e o Experimento do Monocórdio -- o que possibilita inclusive um „link“ com o módulo referente a tal assunto. A conscientização da relação mencionada permite ainda a re-leitura, à luz das Séries de Fourier, de diferentes conceitos e situações a princípio musicais, tais como consonância/dissonância, quintas e oitavas paralelas, etc, fazendo uso de dispositivos audiovisuais reveladores da matemática oculta e simultânea ao processo outrora 
exclusivamente musical.

Nesta sala haverá um painel sobre a história da Série Harmônica, um painel sobre o som e suas propriedades, mais dois painel sobre a representação sonora de Galileo e a relação entre a Série Harmônica e a Série de Fourier acompanhada de uma bancada com um sistema que acopla uma série de instrumentos, um osciloscópio e um analisador de espectros. Com tal dispositivo espera-se que o visitante possa ouvir o som de um instrumento ver a forma de onda gerada no osciloscópio e decomponha esta onda no analisador de espectros, além disso a sala terá um software no qual o visitante pode, a partir da adição de harmônicos compor diversos timbres.

\subsection{Sala 6: Consonância e Dissonância: do simbolismo aritmético a uma concepção} física

Considerando os aspectos matemático-acústicos dos conceitos de consonância/dissonância, esta sala tem o intuito de apresentar diferentes concepções matemáticas de consonância construídas no decorrer da história: razão de números simples por Pitágoras; emissão de duas ou mais notas que soam como uma por Arquitas (Fallas, 1992); coincidência de harmônicos de duas ou mais notas por Zarlino associada diretamente ao MMC entre suas freqüências (Abdunur, 1999, p.211); coincidência das pulsações geradoras das notas em questão por Galileo (Cohen, 1984, p.90); proximidade da raiz harmônica na Série de Fourier; concepção fisiológica de Helmholtz (Helmholtz, 1954) etc. A fim de aclarar tais concepções, a presente sala oferece a audição simultânea de duas ou mais notas, de cuja combinação se pretende avaliar o caráter consonante/dissonante, considerando aspectos matemático-acústicos e fazendo uso da visualização de sua configuração harmônica segundo as Séries de Fourier, o que possibilita ainda um „,link“ 
com a sala Série Harmônica/Série de Fourier.

Nesta sala haverá um painel com a história das consonâncias / dissonâncias em alguns contextos culturais, dois painéis sobre as diferentes explicações físico-matemáticas para tais, um painel sobre a análise das coincidências de harmônicos acompanhados de um experimento e um software nos quais o visitante poderá ouvir e ver a quantidade de coincidências e desencontros entre as frequências duas notas tocadas simultaneamente.

\subsection{Sala 7: O som dos planetas}

Ambientada segundo uma estética que reporte o pensamento do visitante ao espaço sideral, a sala Sons dos Planetas de Kepler apresenta a analogia entre movimento planetário do sistema solar e uma sinfonia - sustentada especificamente pela correspondência entre a velocidade dos planetas e a freqüência de emissão de uma nota musical - segundo duas formas:

- Da maneira como o pensador alemão a apresentou no Harmonia Mundi de 1619 (Kepler, 1619), de acordo com o conhecimento planetário da época.

- Uma versão atualizada da idéia de Kepler, construída a partir dos dados astronômicos atuais.

Ambas construções fazem uso de dispositivos mecânico-eletrônico-musicais que possibilitam visualizar o movimento planetário - em cada caso - simultaneamente a audição dos sons dos planetas. Com o intuito de explorar a experiência imaginativa de Kepler, tais dispositivos munem-se de comandos interativos, tais como a visualização e audição separadamente de uma, duas ou mais órbitas e respectivamente uma duas ou mais linhas melódicas correspondentes. 


\subsection{Sala 8: Da matemática-especulativa à matemática-empírica: uma revolução científica na música}

Durante o Renascimento, ocorre uma intensificação do ceticismo ao pitagorismo em contextos teórico-musicais, especialmente no que concerne ao uso da aritmética especulativa como fundamento para a música. Vincenzo Galilei é representativo do movimento que se opõe à tradição pitagórica segundo a qual somente números naturais por meio de razões matemáticas deveriam explicar conceitos musicais, utilizados de maneira especulativa.

Esse módulo objetiva ressaltar aspectos matemático-musicais que contribuíram para a reestruturação da música teórica nesse período, que passa de uma visão matemáticocosmológico-especulativa para um entendimento matemático-físico-empírico, por meio da leitura histórico-epistemológica à luz de filósofos da ciência, tais como Thomas Kuhn (Kuhn, 1962) e Gaston Bachelard (Bachelard, 1996).

O módulo contará com dois painéis que evidenciarão aspectos relativos à tal mudança de enfoque sobre a música teórica, incluindo o surgimento do conceito de som como vibração, o conceito de consonância como coincidências de vibrações além de outros que evidenciam a forte transformação do caráter especulativo para o experimental. O conteúdo dos painéis levará em conta o uso de conceitos epistemológicos tais como Revolução Científica (Kuhn, 1962) e Obstáculo Epistemológico (Bachelard, 1996) na apresentação desse período histórico.

O módulo contará com dois projetores multimídia. Um deles projetará um vídeo que abordará a problemática exposta nos módulos anteriores, proporcionando uma oportunidade de reflexão sobre as questões apresentadas, assim como uma possibilidade de estabelecer uma visão geral. O outro projetor irá expor frases e figuras dinâmicas 
relacionadas à obra dos filósofos da ciência considerados.

\subsection{Considerações gerais sobre a realização da exposição}

As relações entre a matemática e a música são pouco divulgadas e utilizadas nos âmbitos educacional e cultural. Dentre as possíveis razões para tal quadro, cabe ressaltar a escassez de referências bibliográficas e fontes em geral associada à uma historiografia com pouca tradição nessa área, bem como a dificuldade de acesso a conhecimentos simultaneamente em matemática e música. Além disso, uma grande dificuldade enfrentada, por exemplo, por professores e alunos de física e matemática, e de maneira geral, no âmbito do ensino e aprendizado de ciência e tecnologia é a busca de recursos para motivar o interesse por assuntos aparentemente distantes do cotidiano.

Uma opção para contornar tal situação é o uso de atividades relacionadas com os interesses do público em geral. Nesse sentido, uma abordagem interdisciplinar envolvendo música, física e matemática pode ser uma importante aliada para atingir tal público, na medida em que se aumenta o alcance de possibilidades de sensibilização.

Para sanar tal problema, a elaboração de uma exposição, que faz uso de tecnologias abordando a divulgação de conceitos da interface matemática-música para um público em geral faz-se pertinente, na medida em que tais relações são consideradas obscuras mesmo para pessoas envolvidas diretamente nas áreas de matemática, física e música, que muitas vezes desconhecem relações fundamentais para a compreensão de tal interface. A realização desta exposição vem ao encontro ainda da necessidade de aumentar as possibilidades no âmbito da divulgação científica e tecnológica, na medida em que busca opções para motivar o interesse por assuntos aparentemente distantes do cotidiano.

A tecnologia assume um importante papel nesta exposição, na medida em que 
proporciona ao usuário a possibilidade de interagir com diversos dispositivos eletromecânicos, simulando direta ou analogicamente experimentos associados à história da relação matemática-música.

A exposição contempla ainda uma perspectiva histórico-epistemológica, que desempenha um amplo papel na fundamentação da exposição, estabelecendo vínculos entre concepção de desenvolvimento científico e aprendizagem da ciência. Com o intuito ainda de fortalecer a historiografia da relação matemática-música, esta exposição pretende também oferecer ao público uma reflexão sobre o tema à luz de conceitos epistemológicos de Thomas Kuhn e Gaston Bachelard. Além disso, a exposição ampliará o acervo de um museu de divulgação científica, no caso a Estação Ciência, em uma área carente de fontes, referências bibliográficas e recursos em geral.

Espera-se que esta exposição tenha como resultados a produção dos seguintes materiais e objetivos :

- Produção de um catálogo para a exposição, relevante para as relações entre a matemática e música, dos pontos de vista histórico, epistemológico e didático.

- Disponibilização do catálogo em instituição que assegure o acesso do público e de pesquisadores nele interessados.

- Produção de artigos para periódicos especializados sobre temas abordados na exposição.

- Fortalecimento do Museu Estação Ciência por meio da disponibilização em seu acervo do material elaborado neste projeto, permitindo um alcance significativo de tal material nesse museu mesmo posteriormente à exposição, dado que a Estação Ciência recebe regularmente visitas de escolas e do público em geral, garantindo a continuidade da divulgação da relação entre a matemática e a música.

- Aprofundamento por parte da equipe deste projeto na área de divulgação cientifica das 
relações entre matemática e música, contribuindo assim para a formação de novos profissionais nessa área.

- Elaboração de paradidáticos que possam ser aplicados em escolas especialmente nas áreas de matemática, física e música.

O desenvolvimento das atividades da exposição tem possibilitado, por meio de reuniões sobre a construção dos experimentos, softwares, animações e textos, um avanço expressivo no desenvolvimento de minhas pesquisas sobre acústica e sobre ensino. Neste sentido, a concretização deste projeto tem se mostrado muito importante para o amadurecimento de uma material didático sobre a relação física/matemática/música.

Desta forma, as reuniões com o orientador, com os membros da estação ciência e com a equipe técnica que vem desenvolvendo os materiais tem se mostrado de grande relevância para o aprimoramento de meu trabalho de pesquisa, bem como para meu aprimoramento pessoal, sobretudo em questões relacionadas ao tratamento interdisciplinar do tema. 


\section{CAPÍTULO 5 \\ IMPLICAÇÕES EDUCACIONAIS: \\ DIVERSIFICANDO AS ESTRATÉGIAS DE ENSINO}

\subsection{A física dos instrumentos musicais}

A partir do funcionamento dos instrumentos musicais o ensino da Acústica Musical pode explorar uma perspectiva relacionada ao cotidiano dos estudantes. Tal abordagem propiciará um diálogo em que pode-se utilizar elementos da cultura dos alunos, privilegiando uma perspectiva regional que busca a investigação do funcionamento de diversos instrumentos presentes no cotidiano dos estudantes. De uma perspectiva metodológica esta abordagem permitirá que o professor proponha trabalhos de pesquisa e apresentação de seminários que explorem a relação entre a física e o som produzido por eles.

Com isto muitos conteúdos da ondulatória poderão ser abordados, e assim, o professor poderá possibilitar que os seus alunos construam uma percepção mais ampla sobre:

- Os instrumentos de Corda: Sobre os instrumentos de corda pode-se discutir -- o funcionamento e a geometria das caixas de ressonância, a frequência emitida por uma corda vibrante, os modos de vibração de uma corda vibrante e sua relação com os harmônicos do som e consequentemente com seu timbre.

- Os instrumentos de sopro: Sobre os instrumentos de sopro pode-se abordar a relação entre os comprimentos e geometria dos tubos e as frequências emitidas por eles, seus modos de vibração e o timbre. 
- Os instrumentos de percussão: Por não se tratar de instrumentos melódicos os instrumentos de percussão privilegiam uma discussão sobre a amplificação e o timbre dos instrumentos.

\subsection{Da sensibilização musical à sistematização dos conceitos físicos da ondulatória}

Uma possível abordagem, a ser defendida neste texto, considera que a construção conceitual nas ciências naturais deve ser feita partindo da fenomenologia para alcançar a construção de modelos físicos. Neste sentido, defende-se o caminho da utilização da sensibilização musical para gradativamente apresentar os conceito físicos típicos da ondulatória para explicar os fenômenos observados. Ou seja, modelar só faz sentido quando se conhece o fenômeno que estamos buscando explicar. Tal discussão aparentemente óbvia faz-se necessária a medida que grande parte dos materiais didáticos de física optaram por configurar-se pela apresentação de uma série de conclusões. Assim, as perguntas e as metodologias que conduziram historicamente à estas conclusões desaparecem das discussões. Esta maneira de apresentar a ciência, além de impossibilitar que o estudante acesse a natureza do conhecimento científico, constrói a percepção de uma ciência dogmática e inquestionável, privilegiando um ensino muito factual e pouco reflexivo.

Assim, considera-se fundamental para a discussão sobre a acústica musical que o estudante vivencie, antes de tomar contato com o modelo ondulatório, diversos fenômenos sonoros e que o professor explicite semelhanças e diferenças de uma grande diversidade de sons. Naturalmente esta abordagem exigirá um papel singular para a experimentação no curso de física e desta forma na próxima seção tem-se a pretensão de apresentar um conjunto de estratégias visando o ensino de conceitos da acústica musical. 


\subsection{Diversificando as estratégias de ensino}

Visando explicitar o trabalho com a acústica musical segue abaixo um conjunto de estratégias que podem colaborar com o desenvolvimento de um curso sobre este tema. Vale ressaltar que apesar de abordar algumas estratégias de ensino o presente texto não tem a pretensão de prescrever como deve-se ensinar acústica, mas sim colaborar com os professores para que estes possam explorar outras estratégias e abordagens do assunto.

\subsubsection{O uso de softwares e a relação entre as qualidades do som e os elementos de uma} onda

Um dos objetivos tipicamente almejados no ensino de Acústica é a associação entre as qualidades do som (altura musical, intensidade sonora e timbre) e os elementos de uma onda (amplitude, frequência, comprimento de onda, forma de onda, entre outros). Uma estratégia que pode ser explorada na busca deste objetivo é a utilização de um software que simule um osciloscópio. Há diversos softwares livres disponíveis na internet, mas para exemplificar esta atividade foi utilizado um software chamado Signal Scope.

Assim, é possível mostrar graficamente as ondas produzidas por sons graves, agudos, com volumes maiores e menores, além de explorar uma grande diversidade de timbres de instrumentos ou de diferentes vozes. Segue abaixo exemplos de comparações possíveis de serem exploradas em um curso de Acústica: 


\section{a. Altura Musical}

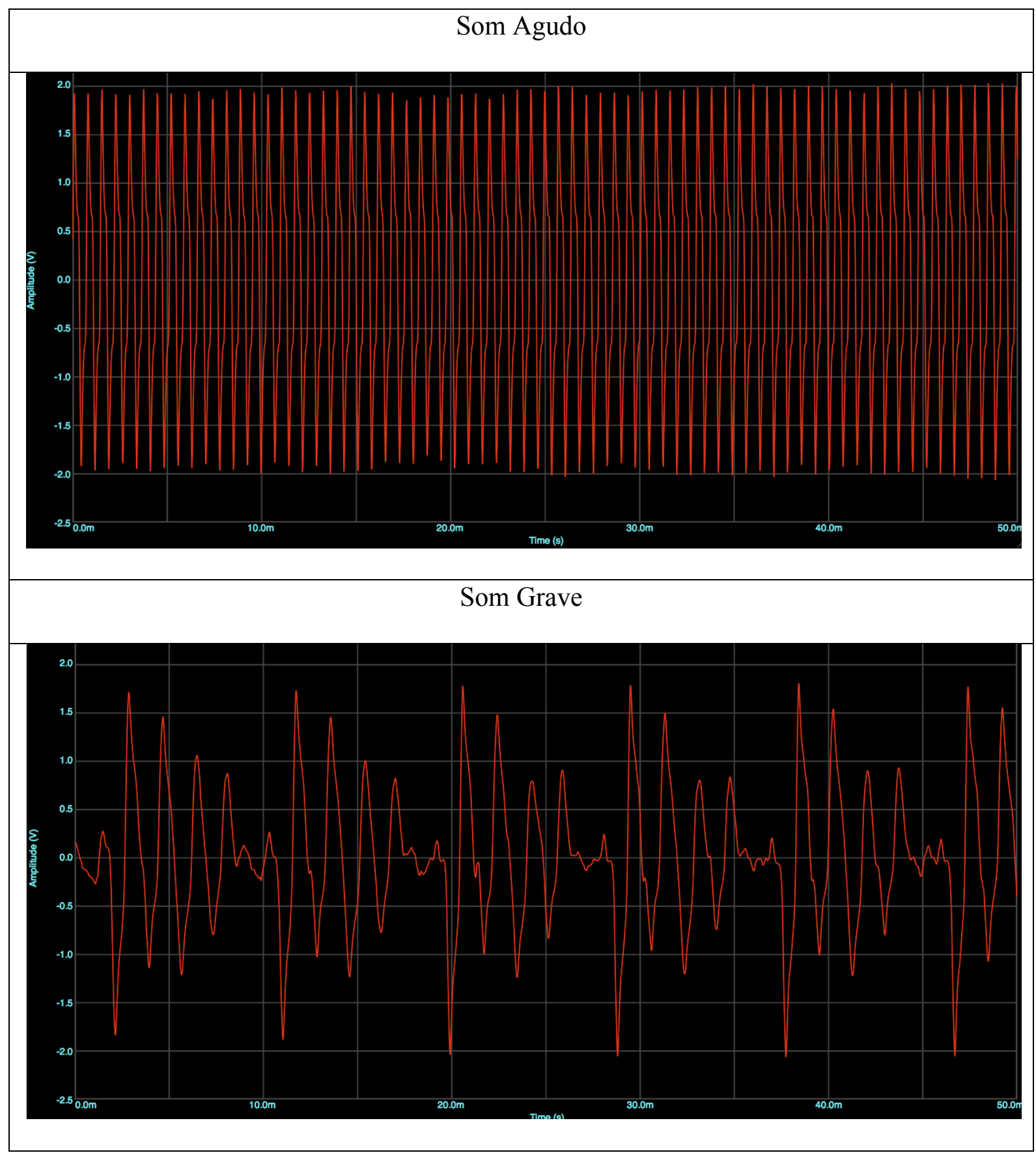

Figura 11: Representação de um som agudo e um grave

Note que a principal diferença entre as ondas apresentadas acima é o período da onda. A partir dele é possível calcular a frequência do som emitido fazendo $f=1 / T$. 


\section{b. Intensidade Sonora}

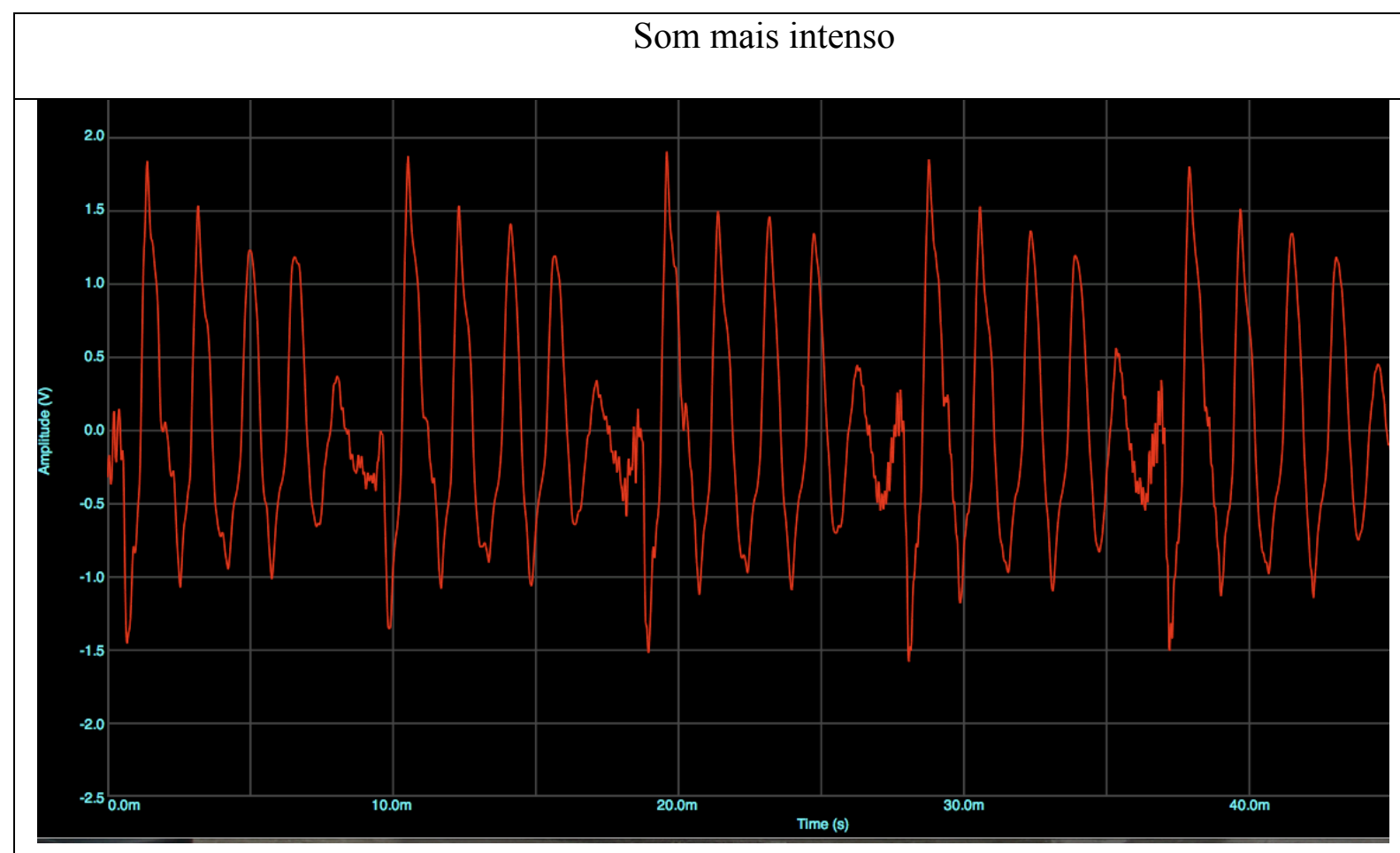

\section{Som menos intenso}

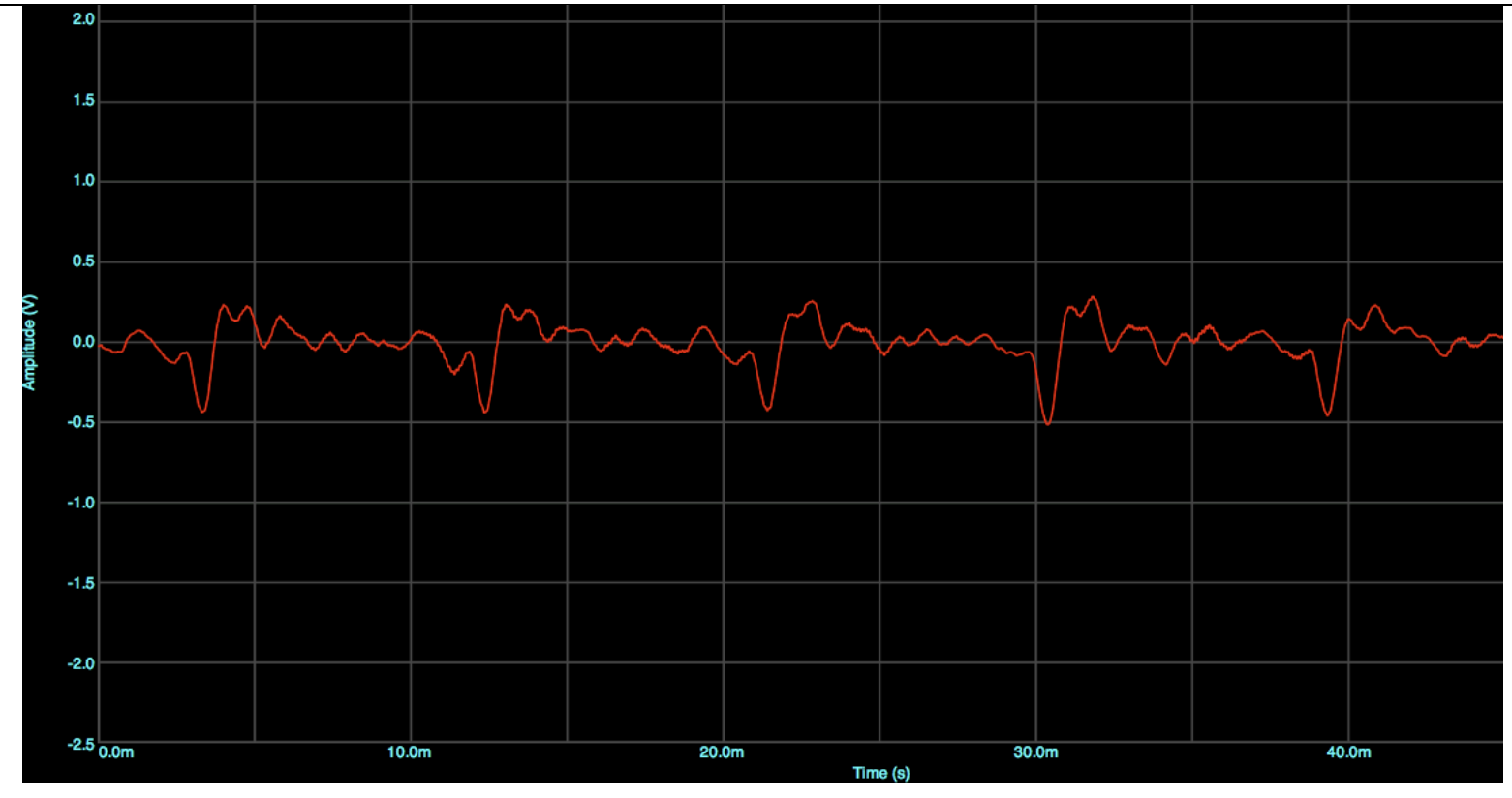

Figura 12: Representação de sons mais e menos intensos 
Note que entre as diferenças das ondas apresentadas acima destaca-se a amplitude das ondas captadas.

\section{c. Timbre}
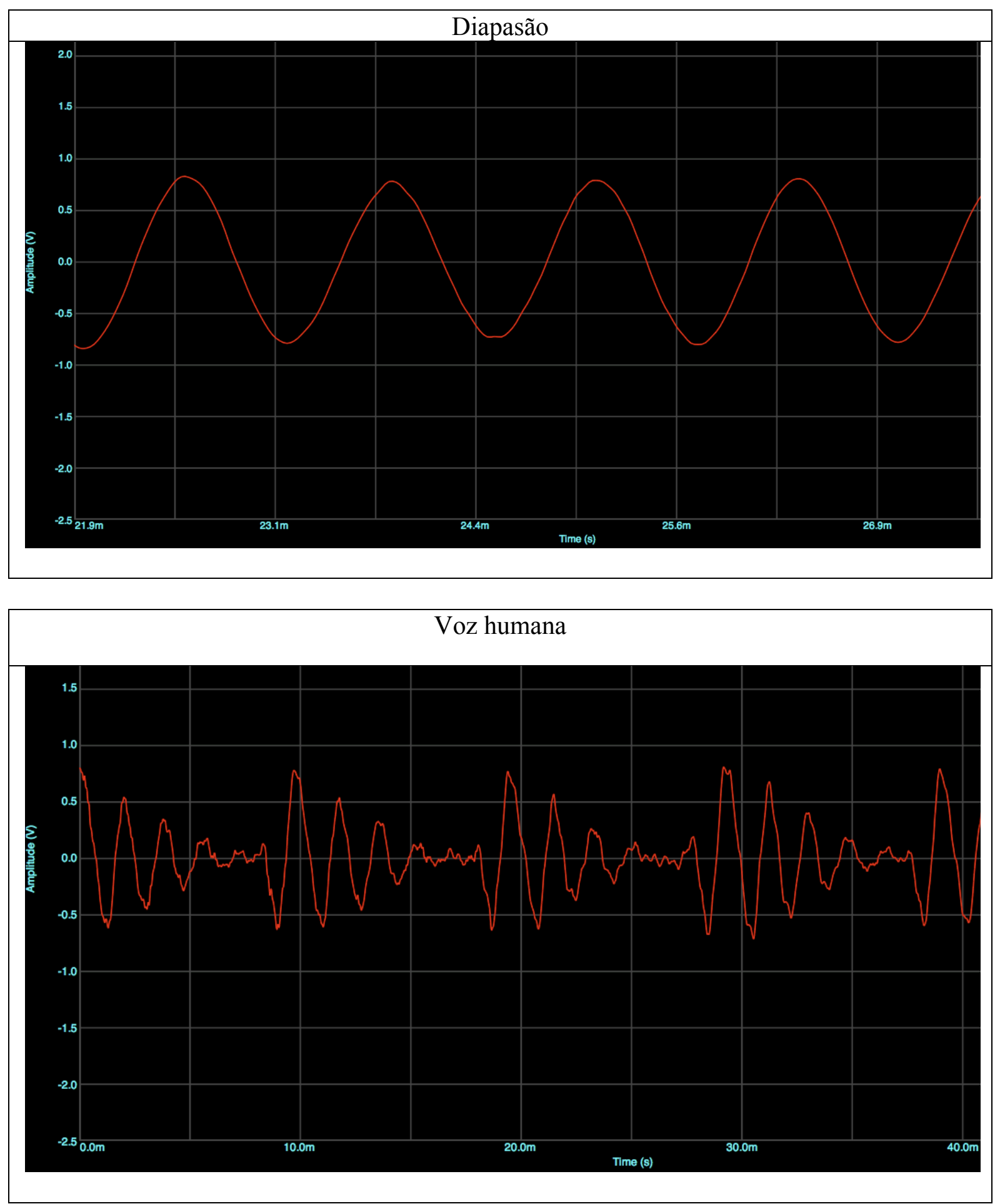

Figura 13: Representação de sons com diferentes timbres 
Note que entre as diferenças das ondas apresentadas destaca-se a forma das mesmas. A apresentação desta discussão permitirá explorar o conceito de Série Harmônica e sua relação com os modos de vibração da fonte geradora deste som. Assim pode-se conduzir os estudantes a compreensão de que ao vibrar com vários modos de vibração um instrumento musical produz diversos harmônicos que quando somados resultam em ondas com formas diferentes. A diferença nas formas de onda são geradas pela amplitude de cada harmônico e é esta característica que diferencia o timbre de diversos instrumentos musicais.

Para explorar esta discussão pode-se utilizar um software ou uma imagem específicos como no exemplo da imagem abaixo.

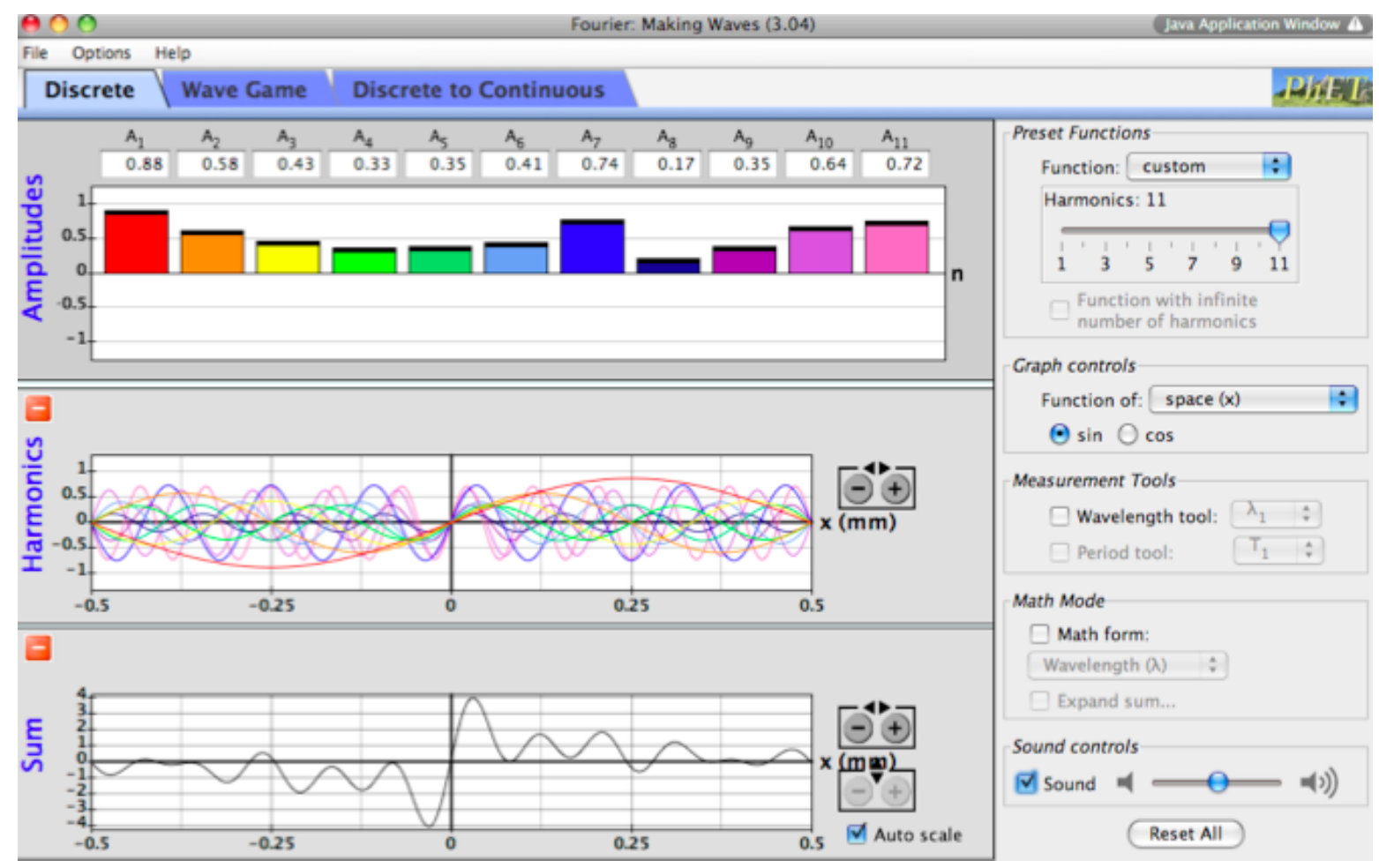

Figura 14: Software Fourier- Making waves 


\subsubsection{A construção de instrumentos musicais como uma estratégia de ensino de}

acústica

Uma importante estratégia a ser explorada neste texto consiste na construção de instrumentos musicais. A complexidade da construção e a profundidade da discussão sobre o funcionamento destes instrumentos deve variar de acordo com o interesse e as possibilidades da escola e dos alunos no assunto. Entretanto, há muitos instrumentos musicais que ao serem construídos propiciam boas e simples discussões sobre ondulatória e acústica. Entre eles destacam-se:

- Os tubos sonoros: Utilizando apenas tubos de PVC e pedaços de carpete é possível cortar os tubos com comprimentos característicos da emissão de determinadas frequências e construir um conjunto de tubos sonoros afinados.

- As flautas de cano de PVC: Adicionando rolhas e furos aos tubos de PVC é possível construir e explorar flautas. A discussão sobre a furação das flautas pode enriquecer significativamente a discussão sobre a relação entre a freqüência emitida pelo instrumento e suas características geométricas.

- Instrumentos de corda: Com uma caixa de ressonância de madeira é possível esticar cordas de diferentes densidades lineares variar seus comprimentos e a tensão que a corda está submetida. Assim pode-se explorar os conhecimentos musicais dos estudantes e tocar músicas conhecidas com o instrumento.

- Instrumentos de percussão: Caixas de fósforos, caixas de madeira, embalagens de pizzas com feijões dentro, entre outros...Estes são exemplos de como pode ser simples construir instrumentos de percussão.

A construção destes instrumentos pode propiciar discussões muito relevantes sobre a natureza do som, seu comportamento e a relação entre a geometria dos instrumentos 
musicais e as características do som por eles emitidos. Assim explorar esta estratégia pode ser enriquecedor para um curso de Acústica.

\subsubsection{A entrevista com músicos e a reflexão sobre a física da música}

Uma outra estratégia para discutir este tema envolve a realização de uma entrevista com um músico. Uma atividade como esta pode trazer uma série de fenômenos ou curiosidades do próprio músico sobre a natureza do som e desta forma pode ser uma boa atividade para disparar perguntas sobre a relação entre a física e a música.

\subsubsection{A leitura de textos históricos e a construção de diálogos fictícios}

Outra estratégia possível de ser abordada é a leitura de textos históricos originais (fontes primárias traduzidas e/ou editadas) e/ou outros textos que remetem as concepções sobre o desenvolvimento histórico da acústica. Tais textos denotam as posições defendidas por físicos matemáticos e filósofos que foram importantes para o desenvolvimento do tema.

São muitos os encaminhamentos possíveis para a leitura destes textos: a produção de fichamentos, resumos, resenhas e reflexões, a apresentação de seminários, as discussões coletivas, mas uma atividade que vale a pena aprofundar a discussão é a construção de diálogos fictícios entre personagens relevantes da história da Acústica. Ao longo do desenvolvimento da exposição didática apresentada no capítulo anterior, alguns diálogos foram construídos pelo grupo de pesquisa "Matemática e música"do professor Oscar João Abdounur. Segue abaixo dois exemplos de diálogos fictícios entre importantes personagens da relação físico-matemático-musical:

\section{Exemplo1: Dialogo entre Vincenzo Galilei e Gioseffo Zarlino}

Personagens: 
1. Vincenzo Galilei (nasceu c. 1520 em Santa Maria a Monte, Toscana e morreu em 1591, em Florença)

2. Gioseffo Zarlino (nasceu c. 1517 em Chioggia e morreu em 1590 em Veneza)

A conversa se daria em 1581

Vincenzo: Salve Gioseffo, tutto bene?

Zarlino: Salve Vincenzo, sto bene grazie! Faz muito tempo que não nos vemos.

Vincenzo: É verdade! Me recordo com nostalgia as aulas de teoria musical que tive com o senhor em Veneza.

Zarlino: Eu me lembro bem dos seus questionamentos. Aliás, como vão os seus estudos sobre a música?

Vincenzo: Têm ido bem, tenho feito experimentos com cordas, tubos e sinos para analisar se as razões simples relacionadas a intervalos de oitava, quinta e quarta são válidas universalmente.

Terceiro Elemento: O que o senhor quer dizer com isso?

Vincenzo: Veja esse monocórdio.Tocando a corda solta e em seguida a mesma corda com metade de seu comprimento, produzimos o intervalo de oitava. Mas será que a razão 1 para 
2 também produz a oitava em tubos, copos, sinos, flautas, martelos, ou seja, em qualquer fonte sonora? Capisci?

Terceiro Elemento: Capisco.

Vincenzo: Meu prezado mestre, e os seus estudos, como vão?

Zarlino: Eu sou um eterno estudante das relações entre a matemática e a música e como músico, espero um dia conhecer uma boa interpretação matemática para conceitos como consonância, dissonância, timbres e etc.

Vincenzo: Eu considero muito obscuro o tratamento pitagórico desses conceitos. Hoje, meu trabalho é fundamentado na verificação experimental, e não no dogmatismo aritmético dos pitagóricos.

Zarlino: Meu sábio colega, por que deveríamos alterar um tratamento que funciona efetivamente há séculos?

Vincenzo: Porque não?

Zarlino: Você não acha que o Universo tem suas regularidades?

Vincenzo: Pode ser, mas isso não implica necessariamente que a música deva se limitar a especulações matemáticas. Por que não estudá-la sob um aspecto experimental? Que mal faria? 
Zarlino: Acredito que nossas observações estão de acordo com a tradição Pitagórica. O fato de a Terra ser esférica, o mundo ter sido feito em 6 dias, e as constatações do experimento do Monocórdio não são evidências "empíricas” da validade da tradição Pitagórica?

Vincenzo: Indiscutivelmente a tradição Pitagórica tem um valor enorme ao longo da história das ciências e da matemática, no entanto me parece razoável que experimentos sejam feitos para confirmar ou contestar conjecturas.

Zarlino: Apesar de compreender seu raciocínio considero que a Tradição Pitagórica já esteja devidamente estabelecida. O que há para contestar? Por exemplo, por meio do Senario, podemos estender os 4 primeiros números pitagóricos para 6, sem ferir essencialmente os princípios pitagóricos. Assim, é possível explicar todas as consonâncias e dissonâncias escutadas por um bom músico utilizando os 6 primeiros números naturais.

Vincenzo: Como?

Zarlino: Os intervalos consonantes são a oitava (1:2), a quarta (3:4), quinta (2:3) e a sexta (4:5 / 5:6). Neste sentido com os números 1,2,3,4,5 e 6 podemos entender o conceito de consonância.

Vincenzo: Mas se eu não estou enganado Pitágoras imaginava que seria possível explicar o mundo somente com os números? Desta forma aos poucos tal tradição acabará incluindo os outros números naturais, racionais, irracionais... 
Zarlino: Acredito que não... Afinal o número 6 está muito bem fundamentado: Deus fez o mundo em 6 dias, o cubo (Poliedro Perfeito) tem 6 faces, são 6 os planetas: Saturno, Júpiter, Marte, Vênus, Mercúrio e a Lua. Logo a consonância pode muito bem ser explicada pelos mesmos 6 números...

Vincenzo: Aparentemente seu argumento é bom, mas não passa de especulação, pois não é apoiado em fatos experimentais. Quem garante que essa interpretação não vá mudar? Para mim o único intervalo indiscutivelmente consonante é a oitava. Tenho dito que ela é a rainha das consonâncias. Quanto aos outros é necessário realizar experimentos que nos ajudem a encontrar uma maneira de classificar quais intervalos são de fato consonantes ou dissonantes.

Zarlino: Continuo a acreditar que a matemática é suficiente para explicar consonâncias musicais assim como todos os fenômenos musicais. Para mim, a música é uma ciência puramente matemática. Ela é perfeita, como o círculo, como o universo, e logo devemos representá-los por números.

Vincenzo: Mamma mia Gioseffo! Que mal há testar nossas afirmações experimentalmente? Aristoxenus já tinha essa visão há quase 20 séculos! Ele desvinculava a consonância de números, tendo uma visão puramente sensorial.

Zarlino: Caro Vincenzo, per me la música pode ser dividida em especulativa e prática, sendo que a especulativa é a mais nobre. Da mesma maneira, a alma que contém o saber supera em nobreza a praticidade do corpo, que é apenas um meio para o saber se consumar. 
Vincenzo: Honestamente, a sua visão numerológica a meu ver é excessiva. Não acredito que tudo possa ser explicado através dos números inteiros. Os números não são sonoros, eles são entidades abstratas. A propriedade de reproduzir um som só pode ser atribuída a um corpo.

Zarlino: De fato temos visões diferentes. Não acredito em testes...(argumentos)...

Vincenzo: Me parece por seus argumentos, que inclusive já se manifestavam desde sua obra Le istitutioni harmoniche publicada em 1558, que o senhor entendeu mal importantes fontes da Antigüidade, como por exemplo, Ptolomeu e especialmente Aristoxenus, cuja grande obra já foi publicada em 1562 em uma tradução latina feita por Gogova.

\section{Zarlino: Como?}

Vincenzo: Comecei a escrever sobre o Le Istitutioni a partir do início dos anos 70, mas a medida em que lia as obras de Aristoxenus e de Ptolomeu traduzidas para o latim e italiano, comecei a enriquecer meu compêndio de modo a modificar substancialmente suas idéias. Tais leituras associadas a meus contatos com o grande humanista fiorentino Girolamo Mei, a quem devo muito de meu conhecimento sobre os modos gregos, definitivamente desencadearam meu interesse por enveredar em um programa que visa corrigir a teoria e prática modernas por meio do exemplo dos antigos sábios.

Zarlino: E como isso está ocorrendo? Você escreveu mais sobre suas idéias? 
Vincenzo: Além do Compendium, recentemente, escrevi a obra Dialogo della musica antica et della moderna, em que exponho novas teorias sobre afinação e modos. Nessa obra eu demonstro, por exemplo, que a afinação usada pela música vocal não é a que o senhor defende, mas deve ser um meio termo entre a diatônica ditoniaion, com suas quintas puras e a diatônica syntonon, com suas terças consonantes. Além disso, demonstro que os modos gregos são completamente diferentes dos modos da igreja.

Zarlino: Aguarde, pois responderei a seus argumentos em uma nova obra que escreverei em breve. Pretendo chamá-la Sopplimenti musicali, e nela, considerarei grande parte dos argumentos que você aqui me coloca, bem como aprofundarei imensamente em Aristoxenus e Ptolomeu.

Vincenzo: Esses meus últimos anos aprofundando sobre importantes fontes da Antigüidade, bem como de contato com grandes humanistas tais como Girolamo me diz que, se o senhor continuar arraigado às doutrinas pitagóricas, não conseguirá dar cabo dessa tarefa. De qualquer forma, aguardo ansiosamente por esta obra para poder respondê-la em algo como um Discorso intorno all'opere di Messer Gioseffo Zarlino.

Zarlino: Quando não te faltar mais argumentos e você tiver respostas menos vazias para explicar fenômenos sonoros, podemos discutir novamente sobre musica da maneira correta. Capisci? 
Vincenzo: Ma como? Zarlino? Quando o senhor (enfático) deixar de lado tanta especulação em favor da importância da experimentação, aí sim nossa conversa poderá tomar rumos mais promissores

Zarlino: Passar bem.

Vincenzo: Passar bem Sr. Zarlino.

Zarlino: De qualquer forma foi um prazer conversar com você. Espero que possamos encontrar a melhor maneira de explicar fenômenos sonoros, podendo assim entender a música de um modo consistente.

Vincenzo: Esperamos...

\section{Exemplo 2: Diálogo entre Pitágoras e Aristoxenus}

Personagens:

1. Pitágoras viveu por volta da segunda metade século VI a.C. (nasceu em Samos)

2. Aristoxenus viveu por volta do século IV a.C. (nasceu entre 375 e 360 a.C. em Tarento e morreu em Atenas)

Aristoxenus está assistindo uma apresentação de lira, divagando ao som da música. até que o senhor ao seu lado comenta:

Senhor: Como é primorosa a técnica da lira! Alia com perfeição o espírito matemático com o musical! Estou estupefato! 
Aristoxenus: Deveras. Por certo, passou anos aprimorando seus ouvidos.

Senhor: Haha, acaso insinuas que seu talento deriva pura e simplesmente do espírito humano? E o conhecimento matemático?! É descartado como cinzas ao vento?

Aristoxenus: Matemática? Vão é o conhecimento matemático como instrumento de aperfeiçoamento musical. É como uma flauta tocada por débeis lábios. A música não está lá para ser calculada, e sim julgada pelo ouvido.

Senhor: Estais a dizer disparates homem. Acaso nunca ouviste falar de meu nome, e de minhas experiências neste ramo?

Aristoxenus: E, quem és tu, ancião?

Senhor: Pitágoras é meu nome. Por certo já o ouviste.

Aristoxenus: Ah, claro, meu pai era seguidor de tuas idéias. Pobre homem. Do que adianta saber a influência do comprimento de onda de uma corda, se você não possui o sentimento para tocá-la harmoniosamente?

Pitágoras: E, como pretendes tocá-la harmoniosamente, se não sabe os pontos onde as razões da corda encontram harmonia? Aliás quem és tu? 
Aristoxenus: Sou Aristoxenus.

Pitágoras: Ouve-se falar muito de você nesses novos tempos. Sabe-se até que eras um seguidor de minhas doutrinas, as quais renunciou em um algum momento, apesar de sua grande admiração por meu discípulo Arquitas. Qual foi o motivo?

Aristoxenus: Quiz conhecer outras doutrinas, como as de Aristóteles, que chegou a indicarme para ser seu sucessor no Liceum, fato esse que me fez ser conhecido como seu seguidor. Tais estudos despertaram em mim outros interesses, tais como harmonia e ritmo; quis conhecer mais a fundo a história da música, os musicistas e as instituições musicais. Além disso, eles me levaram a escrever a obra „Sobre harmonia“, que me deu uma grande fama como filósofo da música.

Pitágoras: E tais conhecimentos não te convenceram ainda da importância da matemática para a música? Por acaso não sabes que somente as razões numéricas formadas pelos números 1,2,3 e 4 podem produzir intervalos musicais harmoniosos ao ouvido? E que intervalos musicais em geral são produzidos por razões de números inteiros?

Aristoxenus: Não nego uma certa associação da matemática com o cálculo de intervalos musicais, mas não com a sensação auditiva. Portanto, não se pode julgar o grau de harmonia de um intervalo musical ou mesmo se se trata de um som musical por razões matemáticas, mas sim pelo ouvido. Lamento, meu senhor, mas não posso concordar com seus argumentos. Suponhamos, por exemplo, que tocássemos no monocórdio um intervalo 
produzido pela razão entre a diagonal e o lado do quadrado. $\mathrm{O}$ meu ouvido o reconhece como um intervalo musical. E na sua visão, o som assim produzido é um intervalo musical?

Pitágoras: Por certo que não! Uma vez que tal razão não pode ser expressa por números inteiros, seguramente não se trata de um intervalo musical, mas apenas de um som. Isto que dizes, por acaso, tem relação com a „suposta descoberta“ (irônico..) de um de meus traidores, quer dizer, seguidores, da existência de grandezas incomensuráveis, dando como exemplo esse mesmo que me dás no momento, a razão entre o lado e a diagonal do quadrado?

Aristoxenus: Certamente!

Pitágoras: Heresia!!!. De acordo com nossa tradição, qualquer razão sempre pode ser expressa como razão de números inteiros. Não foi a toa que não restou outra alternativa a nossos companheiros (talvez correligionários) pitagóricos, senão atirar Hippasus ao mar. Diante de tamanha heresia, era o mínimo que se podia fazer.

Aristoxenus: Isso é simplesmente absurdo. Primeiramente, existem sim razões incomensurávies, ou seja, que não são passíveis de ser expressas como razões de números inteiros. E esse é o caso da razão entre o lado e a diagonal do quadrado, que pelo que me consta, já era conhecida entre seus próprios discípulos. Não há o menor sentido em associar intervalo musical a somente (enfático) razão de números inteiros e portanto, com natureza discreta. Intervalo musical é uma grandeza unidimensional contínua e como tal, qualquer razão comensurável ou incomensurável produz um intervalo musical, cuja a natureza deve 
ser julgada única e exclusivamente pelo ouvido e não pela razão matemática a ele subjacente. Além disso, por ser contínuo, qualquer intervalo pode ser dividido em quantas partes for necessário, diferentemente daquilo que seus discíplos pregram por aí quando dizem que o tom não pode ser dividido em dois semitons iguais. Não somente o divido como considero inclusive o semitom exato como unidade de medida para todos os intervalos musicais.

Pitágoras: Heresia!! Já havia ouvido falar que teves a ousadia de ser o primeiro a desafiar as crenças de minha escola, manifestas em importantes personalidades como Filolaus e Arquitas assim como e nos platonistas, na medida em que não consideras a música como parte da matemática, mas não imaginava que chegava a esse ponto.

Aristoxenus: Meu caro Pitágoras, música não se trata em absoluto de cálculos de intervalos expressos pela razão de dois números inteiros. Admiro os seus feitos no campo da filosofia e da matemática, mas tu deverias saber que música não pode ser reduzida a definições matemáticas, pois é também som. Realmente, todo o conhecimento que vim a ter sobre seus preceitos me parece muito restrito.

Pitágoras: Restrito? É só matemática. E para chegar a tal conclusão, não me baseei apenas na relação entre intervalos musicais e razões matemáticas. Também descobri que para compor um intervalo musical com outro intervalo, basta compor ou decompor a razão da corda que produz o primeiro com aquela que produz o segundo.

Terceiro elemento: Mas o que significa compor e decompor razões e intervalos? 
Pitágoras: A composição da razão a:b com b:c é a:c, o que se traduz no monocórdio em tomármos intervalos musicais contíguos produzidos por tais razões.

Terceiro elemento: Deixe-me ver se bem o compreendi. Isso significa então que o experimento realizado pelos pitagóricos com o monocórdio nos diz que não somente que às consonâncias perfeitas $8 \mathrm{a}$, 5a e 4 a subjazem razões simples $1: 2$, 2:3 e 3:4...

Pitágoras: Sim, mas não apenas isso...

Terceiro elemento: Permita-se continuar...

Pitágoras: Por favor.

Terceiro elemento:... mas ainda que à composição de intervalos musicais subjaz a composição de razões matemáticas, da construção da escala pitagórica?

Pitágoras: Sim!!

Terceiro elemento: Em outras palavras, um importante legado do experimento com o monocórdio dos pitagóricos consiste na ideia de que subir ou descer um intervalo musical dado, corresponde respectivamente a multiplicar ou dividir a razão correspondente a tal intervalo pela razão subjacente ao intervalo que se deseja subir ou descer? 
Pitágoras: Exatamente!

Aristoxenus: Vejo apenas matemática em suas teorias! Pode haver relação entre as coisas que o senhor me coloca, mas no julgamento do som musical, não há o menor sentido em pensar assim. A música deve ser uma disciplina autônoma, completamente separada da aritmética e da astronomia. Não é possível mais nos tempos de hoje a música reduzir-se ao cálculo de intervalos expressos pela razão de números inteiros, pois seu fundamento é o som e não entidades matemáticas. Ainda que possa estar associada ao cálculo de intervalos expressos por razões de números inteiros e que utilize como ferramenta o pensamento racional estabelecendo princípios musicais por meio da investigação de teoremas, passíveis de ser demonstrados; a música no que concerne à sensação auditiva não é uma entidade matemática mas som, som musical diferentemente de ruído e de sons das linguagem falada.

Pitágoras: Absurdo! Como poderia apenas a sensação sem auxílio da matemática estabelecer uma distinção entre intervalos musicais?

Aristoxenus: Quanto à sensação auditiva, eu insisto na necessidade de se treinar o ouvido para se ouvir mais precisamente e no controle a ser exercitado sobre o pensamento racional. Intervalos são entidades puramente musicais e não razões numéricas, que quando consonantes são dados por razões de números 1,2,3 e 4. A música consiste de sons organizados estruturalmente dentro de um espaço sonoro e a função da harmonia é descrever e regular suas relações espaciais e dinâmicas. A partir desses pressupostos, a música deve ser construída a partir de doutrinas aristoléticas. Portanto a música não poderia ser só matemática. 
Pitágoras: Só matemática? Serias tu incapaz de vislumbrar a beleza divina do mundo, expressa pelos números? Por exemplo, a distância da Terra aos planetas visíveis e ao Sol, assim como as velocidades que os corpos celestes circundam a Terra seguem a mesma razão de vários intervalos musicais, especialmente aqueles da escala diatônica, formando a belíssima música dos planetas.

Aristoxenus: Achei meio vago o que me diz... Não ouço esta música dos planetas. Talvez eles estejam um pouco distantes para que meus ouvidos perceba a música deles (ironizando...). Para que tenho ouvidos afinal?

Pitágoras levanta exaltado

Pitágoras: Quer usar seus ouvidos? Ou melhor treiná-los? Pois os abra bem agora. (gritando) TOLO!!!

Pitágoras joga sua coroa áurea em Aristoxenus e se retira.

Aristoxenus se assusta, e, percebe que dormiu na apresentação. Ao se levantar, uma coroa áurea idêntica a que Pitágoras lhe jogou em sonho cai do seu colo.

\subsubsection{O uso de vídeos, imagens e sons}

É absolutamente imprescindível em um curso em que a música e os instrumentos musicais ocupam um papel tão central que se apresente aos estudante vídeos e imagens com 
instrumentos musicais exóticos e sons que possibilitam aos estudantes entender com mais clareza fenômenos sonoros como a ressonância, o batimento, entre outros...

São muitas as possibilidades de exploração destes recursos, dentre elas destaca-se a possibilidade de solicitar aos alunos que busquem materiais para apresentar para a sala e indica-se os vídeos e sons abaixo:

- CD do livro o Som e o Sentido de José Miguel Wisnick: há uma série de sons possíveis de se explorar neste disco, entretanto destaca-se a discussão sobre consonância presente na faixa 26 do disco.

- Série de Luiz Barco “Arte e matemática” - Pode-se utilizar os episódios a música das esferas e a matemática da música.

- DVDs e livros do Grupo UAKTI - Trata-se de um grupo que constrói seus instrumentos musicais, pode-se explorar os vídeos e/ou os livros para analisar como funcionam uma série de instrumentos construídos.

\subsubsection{A experimentação e a construção de conceitos}

Evidentemente este contexto conceitual mostra-se privilegiado para a exploração de uma perspectiva experimental. Assim, a realização de experimentos é uma estratégia importante para abordar este conteúdo. Neste sentido segue abaixo uma lista de experimentos relevantes para a discussão deste tema acompanhada de uma breve explicação dos objetivos e conteúdos que podem ser abordados com a sua realização:

- Mola Oscilante: Trata-se de um experimento muito importante para discutir natureza do som. A partir de uma analogia entre a propagação de energia ao longo da mola pode-se explorar como o som se propaga no ar e ao longo desta discussão explicitar a natureza ondulatória do som. 


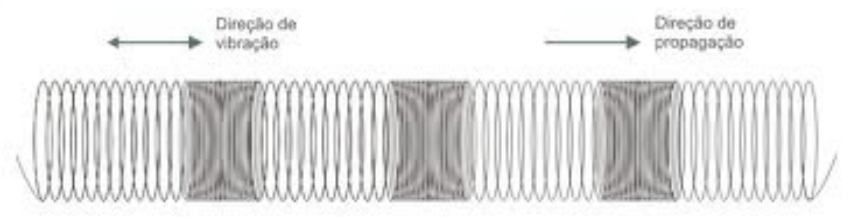

Figura 15: Mola simulando uma oscilação longitudinal

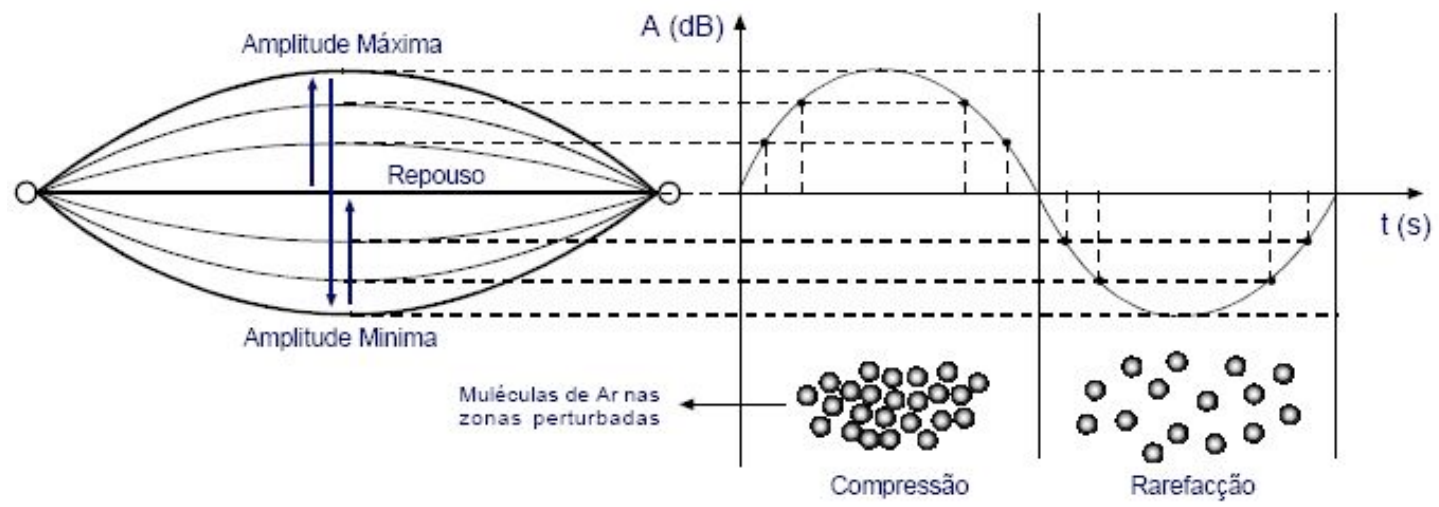

Figura 16: Representação da propagação do som

- Monocórdio, dicórdio e treze-córdio: oferecer a oportunidade para que os estudantes construam e vivenciem o som produzido por um monocórdio pode ser uma boa estratégia para explorar as idéias de Pitágoras e seus seguidores. Utilizando mais de uma corda pode-se explorar o exercício de construção da escala pitagórica.

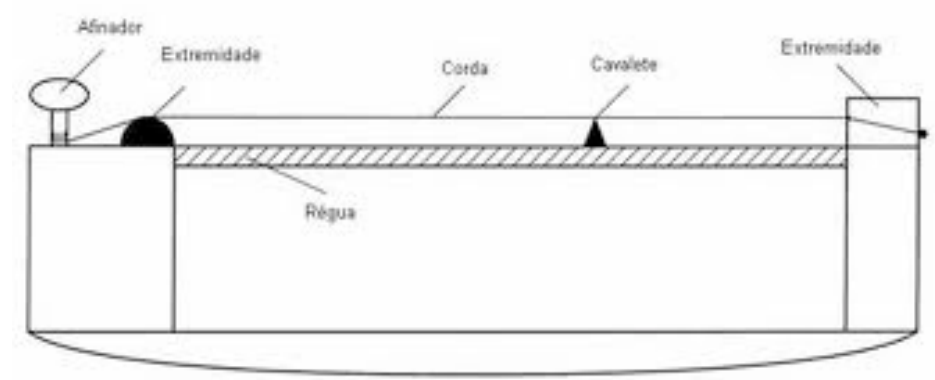

Figura 17: Esquema de funcionamento de um monocórdio 
- Cordas Vibrantes: Evidenciar experimentalmente que uma corda pode ter vários modos de vibração pode ser fundamental para a compreensão dos estudantes sobre o que é timbre.

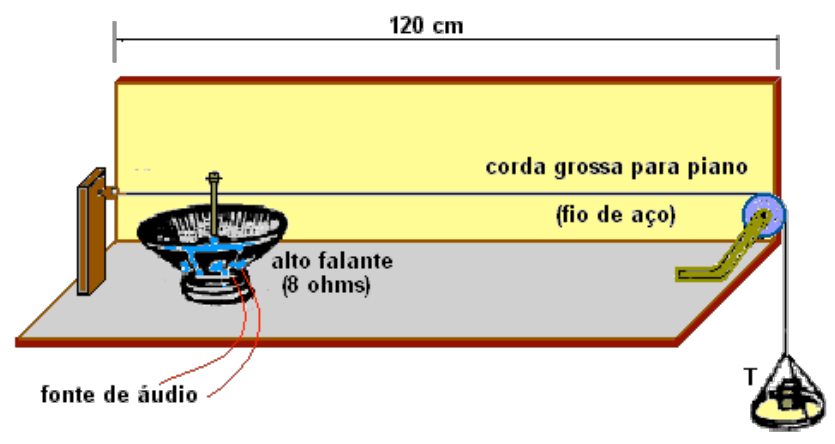

Figura 18: Experimento de cordas vibrantes

- A cuba de ondas: Para sistematizar o comportamento das ondas mecânicas a utilização de uma cuba de ondas pode ser uma ferramenta importante. Note que com este experimento pode-se apresentar uma série de fenômenos que ocorrem com as ondas (reflexão, refração, difração, interferência, entre outros).

Obs.: É possível construir uma cuba de ondas fazendo uso de uma vasilha transparente, um retro-projetor, água e uma agulha de tricô.

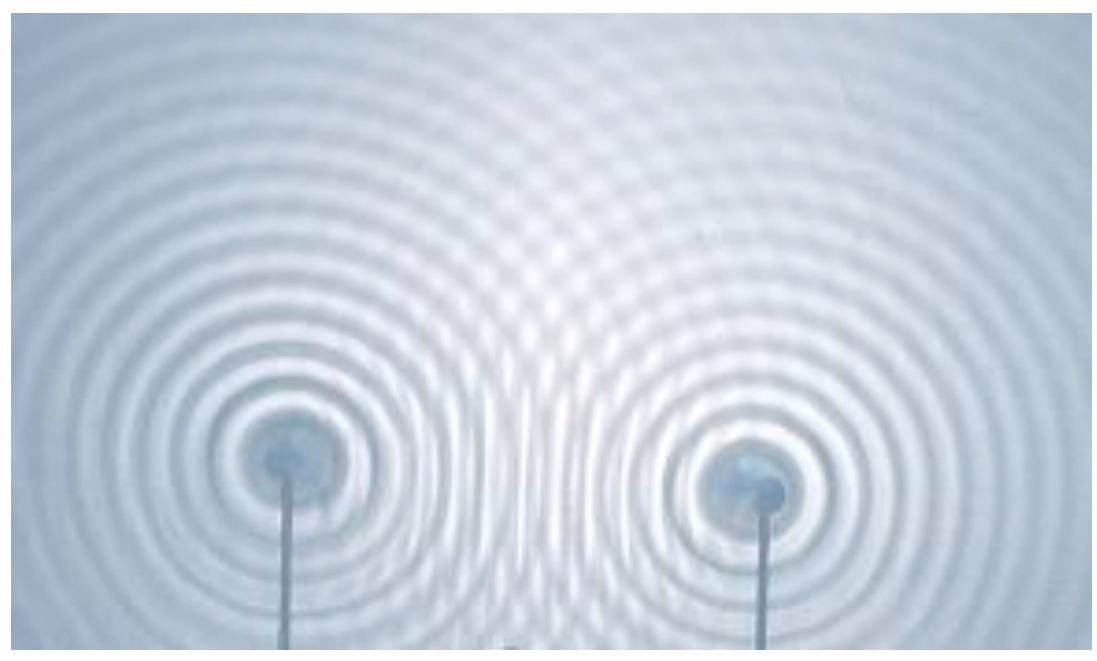

Figura 19: Ondas geradas em uma cuba de ondas 


\subsection{A profundidade e a generalidade desta discussão}

Naturalmente a profundidade desta discussão deve ser balizada de acordo com um planejamento mais amplo a ser realizado pelo professor, pelo número de estudantes que tem interesse por música e pela formação musical dos alunos e do professor. Entretanto, a idéia central que defende-se neste trabalho é que o ensino da acústica musical permite não apenas tratar de um dos mais importantes elementos da relação entre a cultura popular e a ciência, mas também possibilita que o professor explore importantes elementos relacionados à maneira como o conhecimento científico se constrói. Além disso, a apresentação adequada deste conteúdo permitirá aos estudantes construir um amplo e rico repertório de habilidades e competências fundamentais para articulação e utilização do conhecimento científico para olhar para o mundo de acordo com o que é preconizado nos PCNs. 


\section{CONSIDERAÇÕES FINAIS}

Essencialmente este trabalho buscou discutir três importantes perspectivas da relação entre a física e a música, sendo elas:

1. Uma análise histórico-epistemológica da Acústica Musical e sua relação com a importância de contemplar este conteúdo no currículo de física;

2. O desenvolvimento de uma Exposição Didática sobre a relação físico-matemáticomusical e a divulgação de conceitos e ideias do tema;

3. As implicações educacionais deste trabalho e as possibilidades de exploração deste tema em sala de aula.

Assim, buscou-se explicitar como no Renascimento o paradigma científico foi substituído por um novo paradigma no qual a valorização da perspectiva experimental foi de grande importância para a construção de novos conceitos e teorias na acústica.

Além disso, foi organizado um conjunto de estratégias e atividades que podem colaborar com os professores de física para que seus cursos sobre este assunto contemplem a perspectiva musical, os conceitos fundamentais da ondulatória e ao mesmo tempo apresentem uma discussão sobre como os modelos científicos foram construídos.

Neste sentido, é fundamental apontar para as dificuldades de se contemplar este conteúdo no Ensino Médio, já que há uma escassa produção de materiais sobre o assunto, uma fragilidade na formação por parte dos professores e alunos, sobretudo no que diz respeito à formação musical, uma tradição no ensino de física e nos livros didáticos de se abordar este conteúdo superficialmente e uma grande resistência dos profissionais da área em abordar este tema. 
Entretanto apesar das dificuldades de se discutir um tema intrinsecamente interdisciplinar como este, vale ressaltar que esta dissertação buscou explicitar diversas razões para se investir nisso. Dentre estas razões destacam-se a riqueza de se contemplar a perspectiva histórica, valorizar a experimentação (fortemente presente no paradigma científico contemporâneo) e possibilitar a discussão de habilidades, competências e conteúdos fundamentais para a formação de um estudante de física.

Finalmente, vale ressaltar que este texto buscou apresentar, ainda que de maneira superficial e incompleta, o processo de desenvolvimento de uma exposição que tem como principal objetivo divulgar este conteúdo. Naturalmente esta discussão poderá ser aprofundada a medida que a exposição (prevista para acontecer no início de 2011) venha a acontecer. Assim, pretende-se explorar os resultados e avaliações da exposição em um eventual trabalho de doutorado. 


\section{GLOSSÁRIO FÍSICO-MUSICAL}

Acorde: Em música, acorde é a escrita ou execução de dois ou mais notas simultaneamente. Para alguns teóricos, o acorde só se forma a partir de três ou mais notas, reservando a palavra intervalo para a execução de duas notas simultâneas. Os acordes são formados a partir da nota mais grave, onde são acrescentadas as outras notas constituíntes.

Altura musical: Apesar do nome sugerir que a altura é uma qualidade do som relacionada ao volume, a altura musical relaciona-se diretamente à frequência de uma onda sonora. Assim, quanto maior a altura de um som, mais agudo ele é.

Amplitude de uma onda: No contexto da Acústica é muito comum se representar uma onda Sonora pelo gráfico de pressão em função do tempo ou do espaço. Assim, a amplitude de uma onda é definida como a metade da distância de uma crista a um vale como representado pela letra A na imagem abaixo.

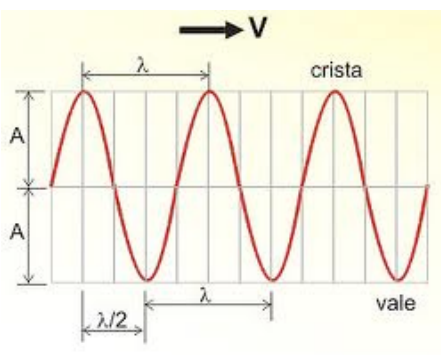

Campo harmônico: Campo harmônico (português brasileiro) ou Campo harmónico (português europeu) é o conjunto de acordes formado a partir das notas de uma determinada escala. Esses acordes são extraídos de uma das quatro escalas estruturais: a maior, a menor, a menor harmônica e a menor melódica. Também pode ser chamado de estrutura tonal visto que o desenvolvimento da harmonia está inteiramente ligado ao aparecimento e 
desenvolvimento do conceito de tonalidade.

Consonância/ Dissonância: Segundo Henrique Dourado - Na harmonia tradicional, uma consonância (do latim consonare, significando soar junto) é uma harmonia, um acorde ou um intervalo considerado estável, em relação a uma dissonância que é considerada instável. Em uma definição mais restritiva a consonância pode ser um conjunto de vibrações sonoras concordantes e portanto aceitas como mais confortáveis ao ouvido em oposição às dissonâncias (grupo de duas ou mais notas que criam forte tensão e se tornam instáveis ao ouvido, que por natureza busca a resolução em acordes consonantes).

Escala Musical: Qualquer sequência de notas organizadas asendentemente ou descendentemente por intervalos previamente definidos.

Frequência: Número de oscilações completas de uma onda por unidade de tempo. Uma unidade de medida amplamente na Acústica é o "Hz" que significa ciclos/s, assim quando se diz que um lá tem frequência de $440 \mathrm{~Hz}$ significa que a onda sonora oscila 440 vezes por segundo.

Harmonia: Em música, Harmonia é o estudo das relações de encadeamento de acordes (conjunto de notas tocadas simultaneamente). Tradicionalmente, obedece a uma série de normas que se originam nos processos composicionais efetivamente praticados pelos compositores da tradição européia, entre o período do fim da Renascença ao início do século XX. 
Harmônicos: são sons individuais e puros que normalmente estão presentes nas notas em que escutamos. Os harmônicos podem ser escutados porque uma coluna de ar ou uma corda podem vibrar, não só como um todo, mas como duas metades, três terços, quatro quartos...O n ésimo harmônico tem comprimento de onda da fundamental dividido por n, e uma freqüência de $n$ vezes a freqüência fundamental. Muitas vezes os harmônicos se misturam com a fundamental dando impressão de ser uma única nota, porém o harmônico pode ser ouvido individualmente.

Intervalos Musicais: "distância” entre duas Alturas musicais. Os intervalos podem ser obtidos através da razão das frequências de duas notas.

Nota: Som cuja a altura musical ( frequência da onda) é definida e pode ser identificada.

Série Harmônica: é um conjunto de sons individuais e puros que normalmente estão presentes nas notas musicais que escutamos. Por exemplo, a nota lá $440 \mathrm{~Hz}$ contém sua oitava, $880 \mathrm{~Hz}$, sua quinta composta, $1320 \mathrm{~Hz}$, sua oitava dupla, $1760 \mathrm{~Hz}$, sua terça bicomposta $2200 \mathrm{~Hz}$ etc. Produzir um som em um instrumento musical significa colocar algum elemento em vibração para que esta vibração seja transmitida ao ar. A freqüência ou altura do som produzido vai depender das características do meio vibratório (uma corda, coluna de ar, etc); os sistemas físicos não vão vibrar de uma única forma, mas sim emitindo diversas freqüências, todas múltiplas da nota fundamental. Estas outras freqüências são os harmônicos ou parciais, e sua composição é o que vai caracterizar o timbre do instrumento. 
Série de Fourier: Qualquer (ou quase) função periódica de freqüência f pode ser representada como uma série de Fourier, ou seja, ser representada como a soma de funções harmônicas de freqüência múltipla inteira de f. Uma nota musical tocada num instrumento contém a freqüência fundamental, que dá a qualidade de tonalidade (por exemplo, o lá padrão de $440 \mathrm{~Hz}$ ), e seus harmônicos, em proporções que lhes são características e lhes dão a qualidade de timbre. A mesma nota tocada em instrumentos diferentes soará com timbres diferentes pelo fato do som gerado por cada instrumento conter os harmônicos do tom fundamental em proporções diferentes. Essas proporções são características de cada tipo de instrumento, e, para o ouvinte mais acurado, características de cada modelo ou exemplar de instrumento. Assim, por exemplo, o som produzido por uma clarineta contém quase que somente harmônicos ímpares, enquanto numa flauta praticamente apenas o primeiro e o segundo harmônico estão presentes.

O som que ouvimos depende apenas da intensidade relativa de cada componente, e não depende das fases de cada componente. Assim, formas de onda muito diferentes, geradas pelos mesmos componentes, mas com fases diferentes, soam iguais.

Timbre: Característica do som que permite que se diferencie o som emitido por diferentes instrumentos musicais. Esta diferença é consequência de formas de ondas diferenter que por sua vez é consequência de cada instrumento apresentar modos de vibração com amplitudes distintas. 


\section{REFERÊNCIAS BIBLIOGRÁFICAS}

ABDOUNUR, OSCAR J. Histórias da relação matemática/música e construção de significados. Editora da SBHMat. Extraído de Facetas do diamante: ensaios sobre educação matemática e história da matemática. John Fossa. 2000, 272 pág.

ABDOUNUR, OSCAR J. Matemática e música: o pensamento analógico na construção de significados. Editora Escrituras. $1^{\text {a }}$ edição, 2000, 352 pág.

ABDOUNUR, OSCAR J.; ADDONO JR, A.A.; PEREIRA, A.A.; PEREIRA, R.A.; PRADO, L.A.G., A relação matemática-música no renascimento: uma abordagem histórico-epistemológica. Trabalho apresentado no X Seminário de História da Ciência. Belo Horizonte, 2005.

BACHELARD, GASTON. A formação do Espírito Científico: contribuição para uma Psicanálise do Conhecimento. Tradução: Estela dos Santos Abreu, Rio de Janeiro, RJ: Editora Contraponto, 1996. 316 pág.

BAILHACHE, PATRICE. Une histoire de l'Acoustique musicale. Paris: CNRS Editions. 2001, 199 pág.

BOYER, C. B. História da Matemática. Tradução de Elza Furtado Gomide. São Paulo: Editora Edgard Blücher, 1999, 488 pág.

COHEN, H. F. Quantifying music. The science of music at the first stage of the Scientific Revolution, 1580-1650. Dordrecht: D. Reidel Publishing Company, 1984.

CULVER, C.A. Musical Acoustics. Philadelphia: McGraw-Hill, 1956.

DESCARTES, RENÉ. BUZON, FRÉDÉRIC de. Abrégé de musique, Compendium musicæ. Paris: Presses Universitaires de France, 1987. 
DOSTROVSKY, S. Early Vibration Theory: Physics and Music in the Seventeenth Century. Archive for history of Exact Sciences, XIV,1975,169-218 pág.

DOURADO, A.H. Dicionário de termos e expressões da música. São Paulo: Ed. 34, 2004.

EGAN, J.B. Marin Mersenne, Traité de l'harmonie universelle: Critical Translation of the Second Book. PhD dissertation, Indiana University, 1962.

EVES, H. Introdução à História da Matemática. Trad. Hygino H. Domingues. Campinas, SP: Editora Unicamp, 1995, 844 pág.

FEYRABEND, P. Contra o método. Tradução de Octanny S. da Mota e Leonidas Hegenberg. Rio de Janeiro: F. Alves, 1977, 488 pág.

GALILEI, VINCENZO. Dialogo di vincentio galilei nobile Fiorentino della musica a ET della moderna. In Fiorenza. M.D.LXXXI. Roma, Biblioteca Nazionale.

GALILEI, VINCENZO. Discorso intorno alle opere di Gioseffo Zarlino ET altri importanti particolari attenenti alla musica. Firenze M.D.LXXXI. Bollettino bibliográfico musicale, Milano.

GOSSETT, P. Preface to Jean-Philippe Rameau: Treatise on Harmony. New York, 1971.

HENRIQUE, L. L. Acústica musical. Lisboa: Fundação Calouste Gulbenkian, 2002.

JEANS, J. Science \& Music. Cambridge, England: Cambridge University 1937; reprinted, Dover, New York, 1968. 
KEPLER, JOHANNES. Ioannis Keppleri Harmonices Mundi libri V. Frankfurt A.M. et Erlangæ Heyder \& Zimmer, 1619, Vol. V.

KUHN, THOMAS S. The structure of scientific revolutions. Chicago: University of Chicago Press, 1970.

KUHN, THOMAS S. A estrutura das revoluções científicas. São Paulo: Editora Perspectiva, 1978.

KUHN, THOMAS S. A tensão essencial. Lisboa: Edições 70, 1977.

LINDSAY, R.B. Acoustics: Historical and Philosophical Development. Stroudsburg: Dowden Hutchinson \& Ross edition, 1973.

MENEZES. L. C. Rever o quê, mudar por quê. Revista Acesso, Revista Acesso: revista de educação e informática, n.14, São Paulo: FDE, dez. 2000, pág. 29-34.

MILLER,D.C. Anedoctal History of the science of sound to the Beginning of the 20th Century. New York: Ed. Macmillan, 1935, 114 pág.

OLSON, H.F. Musical Engineering. New York : McGraw-Hill, 1952, 369 pág.

PALISCA, CLAUDE V. Vincenzo Galilei, scienziato sperimentale, mentore Del figlio Galileo. Annaldi di Storia della Scienza. Nuncius. Anno XV, 2000, fasc. 2. Firenze.

PALISCA, CLAUDE V. Scientific Empiricism in Musical Thought. Princeton: Seventeenth Century Science and the Arts, ed.H.H.Rhys, 1961, pág 91-137.

POPPER, K. A lógica da pesquisa científica. São Paulo: Editora Cultrix, 1975.

ROEDERER, J. G. Introdução à física e psicofísica da música. São Paulo: EDUSP, 1998. 
RIBEIRO, A. A. UAKTI: um estudo sobre a construção de novos instrumentos musicais acústicos. Belo Horizonte: Editora. C/Arte, 2004.

STANLEY, S. Dicionário Grove de Música: edição concisa. Rio de Janeiro: Jorge Zahar Ed., 1994, 1048 pág.

TAYLOR C.A. The Physics of Musical Sounds. Londres: English Universities Press, 1973.

TRENTIN, E. Os instrumentos musicais como recurso didático no ensino de acústica. São Paulo: Dissertação de mestrado apresentada ao IFUSP e à FEUSP, Orientadora Jesuina L. de A. Pacca, 2003.

TRIVELATO,S.L.F. Ciência/Tecnologia/Sociedade - Mudanças Curriculares e Formação de Professores. São Paulo: tese de doutoramento FEUSP, 1993.

WISNIK, J.M. Som e o sentido: uma outra história das músicas. São Paulo: Círculo do Livro, 1989.

ZANETIC, J. Física também é cultura. São Paulo: Tese de doutorado, Universidade de São Paulo, 1989.

ZARLINO, G. Le istitutioni harmoniche. Venetia: appresso Francesco Senese, 1562.

ZARLINO,G. Sopplimenti musicali del R.M. Venetia: Mastro di cappella della sereníssima signoria di Venetia,1588.

ZYLBERZTAJN, A. Revoluções científicas e ciência normal na sala de aula. In: MOREIRA, M. A.; AXT, R. Tópicos em Ensino de Ciência. Porto Alegre, Sagra:1991. 